\title{
Magmatic-to-hydrothermal crystallization in the W-Sn mineralized Mole Granite (NSW,
} Australia): Part II

Evolving zircon and thorite trace element chemistry

\author{
Journal Article \\ Author(s): \\ Pettke, Thomas; Audétat, Andreas; Schaltegger, Urs; Heinrich, Christoph A. (D) \\ Publication date: \\ 2005-08-05 \\ Permanent link: \\ https://doi.org/10.3929/ethz-b-000048110 \\ Rights / license: \\ Creative Commons Attribution-NonCommercial-NoDerivatives 4.0 International \\ Originally published in: \\ Chemical Geology 220(3-4), https://doi.org/10.1016/j.chemgeo.2005.02.017
}




\section{Magmatic-to-hydrothermal crystallization in the W-Sn mineralized Mole Granite (NSW, Australia) Part II: Evolving zircon and thorite trace element chemistry}

Thomas Pettke $^{*}$, Andreas Audétat ${ }^{+}$, Urs Schaltegger ${ }^{\diamond}$ and Christoph A. Heinrich*

* Isotope Geochemistry and Mineral Resources, Dept. Earth Sciences, ETH Zentrum NO, CH-8092 Zürich, Switzerland

${ }^{+}$Institute of Mineralogy, Wilhelmstrasse 56, D-72074 Tübingen, Germany.

${ }^{\natural}$ Département de Minéralogie, Université de Genève, Rue de Maraîchers 13, $\mathrm{CH}$ 1205 Genève, Switzerland

Corresponding author: Thomas Pettke pettke@geo.unibe.ch

Please cite as:

Pettke, T., Audetat, A., Schaltegger, U., and Heinrich, C. A., 2005. Magmaticto-hydrothermal crystallization in the W-Sn mineralized Mole Granite (NSW, Australia) - Part II: Evolving zircon and thorite trace element chemistry.

Chemical Geology 220, 191-213.

DOI: 10.1016/j.chemgeo.2005.02.017 


\section{Abstract}

The Sn-W mineralized Mole Granite in Eastern Australia hosts zircon populations that crystallized at several stages during a protracted magmatic to hydrothermal evolution. Thirty-four elements have been quantified by laserablation inductively-coupled-plasma mass-spectrometric microanalysis with the aim of relating the chemistry of zircon to its growth environment. Trace element contents are highly variable for all textural occurrences. Zircon inclusions in earliest quartz phenocryst suggest that zircon was a liquidus phase that crystallized probably deep in the crust. Trace element contents are conspicuously high, showing only a slight positive Ce anomaly but a pronounced negative Eu anomaly. Successive crystallization stages of magmatic zircon are characterized by progressive depletion in trace element contents, notably the rare earth elements, with an increasingly important positive Ce-anomaly. This evolution reflects saturation of REE accepting minerals such as monazite, thorite, xenotime and possibly apatite and is affected little by the exsolution of a magmatichydrothermal fluid. Zircon that is interpreted to have precipitated from aqueous fluids in Sn-W-bearing quartz veins shows REE patterns indistinguishable from those of late-magmatic zircon. When combined with experimental evidence on the fluid - melt partitioning of REE it indicates that the REE distribution coefficients for zircon / melt and zircon / fluid are largely comparable.

The second example of hydrothermal zircon crystallized some 2 Myrs after the host granite. These crystals reveal an intragranular zonation of increasing trace element concentrations from core to rim. Therefore, REE abundances and patterns alone are not conclusive indicators of the geological environment in which zircon crystallized. Nevertheless, variations in trace element contents of zircon that relate to the chemistry of the melt or fluid from which zircon crystallized, as measured in cogenetic melt and fluid inclusions, are promising for future petrogenetic modeling.

Lead and Cs are strongly incompatible in hydrothermal zircon, with estimated zircon-fluid distribution coefficients $D \leq 0.001$, while Sn and Li are moderately incompatible, $\mathrm{D}_{\mathrm{Sn}} \sim 0.6$ and $\mathrm{D}_{\mathrm{Li}} \sim 0.1$, and $\mathrm{Ce}$ is compatible, $\mathrm{D}_{\mathrm{Ce}} \sim 14$. Moreover, 
hydrothermal zircon has a more pronounced negative Eu-anomaly and higher $\mathrm{Ta} / \mathrm{Nb}$ and $\mathrm{U} / \mathrm{Th}$ ratios than the magmatic zircons of the Mole Granite.

\section{Keywords}

Hydrothermal zircon, granite, trace element partitioning, Pb, LA-ICPMS

\section{Introduction}

Zircon is most widely used for U-Pb dating of magmatic events, because of its resistance to post-crystallization overprinting, which is manifested by the preservation of complex internal structures and chemical zonation patterns. The processes controlling the minor to trace element chemistry of zircon, however, are not well constrained, nor is much known how the chemistry of natural zircon may vary with the crystallization conditions, from magmatic to hydrothermal stages. Examples in the literature (e.g., Hinton and Upton, 1991; Guo et al., 1996) document variability in trace and rare earth element (REE) patterns of genetically different types of zircon, suggesting that naturally grown zircon may have distinct trace element characteristics as a function of growth environment. Recent experimental evidence, however, suggests that the incorporation of trace metals of less than $4^{+}$valence into $\mathrm{Zr}^{\mathrm{IV}} \mathrm{SiO}_{4}$ is limited by the ability of the zircon structure to accommodate charge-compensating elements such as $\mathrm{P}^{5+}$ (Hanchar et al., 2001; Finch et al., 2001), according to the coupled xenotime-type substitution

$$
\mathrm{M}^{3+}+\mathrm{P}^{5+} \rightarrow \mathrm{Si}^{4+}+\mathrm{Zr}^{4+}
$$

If directly applicable to natural zircon, these data would suggest that the trace element chemistry of zircon may generally not be useful as an indicator of provenance. Indeed, zircon crystals from a range of rock types have been reported to vary little (Hoskin and Ireland, 2000).

Among the trace elements incorporated into zircon, REE are very prominent and thus hold potential for petrogenetic modeling for cases where coeval accessory minerals such as monazite, xenotime, allanite or apatite are also considered (e.g., Condie, 1978; Hoskin et al., 2000, Poitrasson et al., 2002). While there is a fair amount of published data on REE partitioning between zircon and felsic silicate melts (e.g., Hinton and Upton, 1991, Guo et al., 1996; Thomas et al., 2002), there are only few contributions (summarized in Reed et al., 2000) dealing 
with REE partitioning between an aqueous fluid and a silicate melt. No direct data exist, to our knowledge, on the trace element partitioning between an aqueous fluid and zircon at $P$ and T relevant here. Reed et al. (2000) have demonstrated experimentally that partitioning of the REE between a peraluminous monzogranitic melt and a chlorine-bearing, sulfur- and carbon-free aqueous fluid $\left(800{ }^{\circ} \mathrm{C}\right.$ and 200 $\mathrm{MPa}$ ) is strongly controlled by the total amount of $\mathrm{Cl}^{-}$in the aqueous fluid phase. Rare earth elements occur as chloride complexes in the aqueous fluid, hence their concentration is dependent on the bulk salinity of the fluid. Enrichment of LREE in the aqueous fluid coexisting with silicate melt, thereby, is more pronounced than that of MREE and HREE, for all the experiments of Reed et al. (2000), consistent with results from a natural system showing a systematic enrichment in the LREE relative to the HREE in natural high-salinity fluid inclusions ( $80 \mathrm{wt} \% \mathrm{NaCl}_{\text {equiv; }}$; Banks et al., 1994). These observations collectively suggest that a distinct trace element signature enriched in LREE can be expected to exsolve from a silicate melt and that such a signature might characterize zircon precipitating from an aqueous hydrothermal fluid.

The possibility of hydrothermal zircon crystallization (Claoué-Long et al., 1990; Rubin et al., 1993; Kerrich and King, 1993; Kerrich and Kyser, 1994, Yeats et al., 1996; Nesbitt et al., 1999) was received with much skepticism in the literature (e.g., Corfu and Davis, 1991; Claoué-Long et al., 1992), despite extreme mobility of zirconium demonstrated for a tourmalinized granite in Cornwall (Alderton et al., 1980). Evidence for the existence of hydrothermal zircon includes petrographic criteria such as its modal abundance and the types of inclusions in zircon. Kerrich and King (1993) and Nesbitt et al. (1999) reported extreme zircon enrichment in hydrothermally altered rocks compared to the protolith, and these zircon crystals contained inclusions of aqueous fluid and ore minerals of hydrothermal origin. Rubin et al. (1993) documented the presence of hydrothermal zircon crystals in replacement bodies of fluorite in limestone. Finally, various hydrothermal experiments demonstrated the mobility of $Z r$ in aqueous solutions (Aja et al., 1995; Watson et al., 1997) but there are hardly any Zr concentrations from natural hydrothermal fluids published up to date (two concentrations of 18 and $4 \mu \mathrm{g} / \mathrm{g}$, respectively, are published in Audétat et al., 2000a). 
Laser-ablation inductively-coupled-plasma-mass-spectrometry (LA-ICPMS) has made it possible to analyze - during a single ablation - major to trace element concentrations in minerals, and multiphase bulk inclusions in minerals, without the need to expose them to the sample surface, such as fluid (e.g., Günther et al., 1998, Heinrich et al., 2003) and melt (e.g., Audétat et al., 2000a; Halter et al., 2002; Pettke et al., 2004) inclusions. This paper attempts to characterize the major to trace element chemistry of zircon and coexisting thorite grown during progressive melt fractionation from magmatic up to, and including, hydrothermal crystallization, based on the example of the Sn-W mineralized Mole Granite in Eastern Australia. It was anticipated that there could be a set of trace elements (including REE) that could unequivocally fingerprint crystallization of zircon from an aqueous hydrothermal fluid. We hypothesize about the response of hydrothermally grown zircon on the complex fluid compositions of natural systems (based on fluid inclusion chemical data by Audétat et al., 1998, 2000a,b). The data set presented here is part of a larger effort to better characterize the chemistry of accessory minerals that crystallized during the magmatic-hydrothermal transition of a crystallizing pluton and associated magmatic-hydrothermal mineralization. Uranium-lead age data on magmatic and hydrothermal zircon, monazite and xenotime, and complementing trace element chemistry are discussed in the companion paper of Schaltegger et al. (2005).

\section{The Sn-W mineralized Mole Granite}

The Mole Granite belongs to a series of late leucogranites that are part of the large New England Batholith (Fig. 1 in Schaltegger et al., 2005; see also Audétat et al., 2000a,b) emplaced between 270 and 225 Ma along an Andean-type continental margin on the east coast of Australia (e.g., Flood and Aitchison, 1993). This granite is geochemically and mineralogically very homogeneous at the level of exposure (Audétat, 1999), despite the existence of three distinct textural variants. The pluton has a porphyritic 10-100 m thick carapace, and the main body of the intrusion is composed of seriate granite. Both rock types are cut by dikes and irregular masses of microgranite (Audétat et al., 2000a). More than 1200 small ore deposits occur within the intrusion and the overlying country rocks, and most of them have been mined for either Sn, W or base metals (e.g., Henley et al., 
1999). Some of these hydrothermal ore veins contain free-grown hydrothermal quartz in open cavities that host a variety of mineral inclusions including zircon, thorite, potassium feldspar, ilmenite, topaz, monazite, fluorite, biotite, beryl, helvite $\left(\mathrm{Mn}_{4} \mathrm{Be}_{3}(\mathrm{SiO} 4)_{3} \mathrm{~S}\right)$, sulfide minerals, muscovite, tourmaline and cassiterite. The hydrothermal minerals precipitated from an aqueous magmatic fluid (coexisting brine and vapor) upon cooling and progressive dilution by meteoric water (Audétat et al., 1998; Audétat, 2000b).

\section{Sample localities and description}

Zircon, thorite and a few monazite crystals from fresh and hydrothermally affected granite and from free-grown hydrothermal quartz of Sn-W ore veins were analyzed for their major to trace element contents. In order to minimize the possibility of multiphase crystallization, recrystallization or hydrothermal overprinting associated with Sn-W mineralization, we analyzed only crystals occurring as inclusions in single quartz crystals of either magmatic or hydrothermal origin (Fig. 1). Crystals in the rock matrix were disregarded here. Zircon inclusions in quartz are often clear and commonly up to $60 \mu \mathrm{m}$ in size. Thorite inclusions are transparent brown crystals that are morphologically identical to zircon (i.e., tetragonal) but often produce a conspicuous brown halo in the surrounding quartz. Monazite entirely included in quartz phenocrysts is microscopically indistinguishable from zircon and occurs only rarely.

Petrographic and age criteria were used to distinguish four different groups of zircon, thorite, and monazite samples according to their stage of crystallization.

These are: (1) early magmatic; (2) late magmatic; (3) hydrothermal zircon; and (4) zircon associated with biotite-dominated hydrothermal alteration that postdates the crystallization of the host granite by ca. 2 Myrs (Schaltegger et al., 2005). These four groups are now described in detail.

(1) Early magmatic zircon was sampled from quartz phenocrysts of a macroscopically unaltered porphyritic granite (sample "vnlt" from locality Pheno, coordinates: GR 360.9E/6765.9N). Phenocrysts are equal proportions of quartz and potassium feldspar with subordinate plagioclase and traces of biotite hosted in a mineralogically identical groundmass of sub-millimeter grain size. Accessory minerals include zircon, apatite, monazite, ilmenite, topaz and fluorite, of which 
zircon, apatite, and ilmenite were found as inclusions in quartz phenocrysts. Judging from the presence of ca. $40 \mathrm{vol} \%$ of phenocrysts in this rock, zircon inclusions in the phenocrysts are expected to have crystallized early in the magma, suggesting that zircon was a liquidus phase (compare Watson, 1979). Cathodoluminescence $(C L)$ images for this type of zircon (Fig. 2a) reveal an early magmatic low-luminescent core termed growth Stage $A$, which is overgrown by oscillatory zoned zircon of magmatic growth Stage B. Growth of this early stage is dated at $247.6 \pm 0.4 \mathrm{Ma}$, by U/Pb on abraded zircon crystals (Schaltegger et al., 2005).

(2) Early to late magmatic zircon co-existing with brown thorite and clear monazite as inclusions in phenocrystic quartz was sampled from a seriate granite (sample "Yank 8.1E" from the Kathida mine, Yankee Lodes, coordinates: GR $351.5 \mathrm{E} / 6759.9 \mathrm{~N})$. Seriate granite contains the same mineralogy as the early magmatic porphyritic granite described above, but is characterized by a more uniform grain size distribution. Quartz phenocrysts host zircon, thorite, monazite, xenotime, feldspar, biotite, topaz, fluorite and crystallized melt inclusions in primary growth zones. Partial replacement of potassium feldspar in the matrix by sericite suggests some hydrothermal overprinting of this sample, likely to be associated with the nearby Sn-W-quartz mineralization. Sector zoning, corresponding to growth Stage $B$, is observed in $C L$ for zircon crystals cut perpendicular to their c-axis (Fig. 2b). A few grains show a somewhat higher luminescent rim that is darker in a back-scattered electron (BSE) image (Stage B1) and apparently cuts the magmatic oscillatory growth zonation in some instances (Fig. 2b,c). These features probably result from interaction of zircon inclusions with hydrothermal fluids invading the quartz phenocrysts along cracks (as evidenced by some secondary fluid inclusions). The CL image for the Yankee Lodes zircon shown by Schaltegger et al. (2005; their Fig. 2c) has a dark CL rim that was not observed for zircon inclusions in quartz crystals analyzed here. This suggests that crystals of zircon included in quartz and in the rock matrix underwent somewhat different histories during and possibly after crystallization. The growth stages of zircon, thorite and monazite inclusions in quartz cannot be texturally related to the crystallization history of the seriate granite, but at least some of the zircon and thorite crystals are likely to have grown late in the crystallization history 
of this rock. Therefore, zircon and thorite inclusions analyzed from this sample are likely to cover a larger crystallization interval than those from the porphyritic granite"vnlt". The monazite age of $247.7 \pm 0.5 \mathrm{Ma}$ is interpreted to be equivalent to zircon Stage B crystallization; hence, these two zircon growth stages appear coeval (Schaltegger et al., 2005).

(3) Hydrothermal zircon and thorite from samples "Yank 7" and "Yank 20" are hosted by $\mathrm{cm}$-sized hydrothermal quartz crystals sampled from open vein cavities at the Kathida tin mine, Yankee Lodes (coordinates: GR 351.5E/6759.9N). The small zircon crystals (commonly between 10 and $25 \mu$ ) occur on primary quartz growth zones that predate the bulk of cassiterite precipitation. Among these, one growth zone is particularly enriched in zircon and thorite crystals (cf. Audétat et al., 2000a, their Fig. 8). Fluid inclusion data indicate that this zircon coexisted with a magmatic fluid at about $600{ }^{\circ} \mathrm{C}, 9 \mathrm{MPa}$, and that this fluid was characterized by elevated contents of F, Sn, and W (Audétat et al., 2000a,b). Zircon and thorite crystals are often isometric, multifaceted and aggregated to clusters comprising a few individual crystals (Fig. 1). This crystal shape closely resembles the descriptions of hydrothermal zircon associated with mesothermal gold lodes in the Abitibi Greenstone Belt in Canada (Claoué-Long et al., 1990). Tension cracks in the quartz host surrounding the crystals are often observed. Some of the crystals show a "spongy appearance", caused by the presence of numerous fluid inclusions. Other inclusions are thorite, potassium feldspar, opaque phases, and possibly xenotime. Potassium feldspar is sometimes directly attached to the zircon and thorite crystals. Apatite was never observed. Cathodoluminescence images reveal variable features for these zircon crystals. Rare, large grains (not shown in Fig. 2) reveal a core of oscillatory zonation (tentatively identified as growth Stage B), discordantly overgrown by a high-luminescent rim, itself overgrown by a thin margin that is zoned parallel to the crystal surfaces. Such crystals may represent inherited magmatic zircon. Most grains (Figs. 2d,e) depict luminescent lobe-like, internally zoned, irregular patches alternating with virtually non-luminescent patches that do not correlate with crystal surfaces, and are together defined as hydrothermal growth Stage D. The combined evidence of the presence of zircon and thorite crystals as primary inclusions in hydrothermal quartz, their multifaceted crystal shape, their peculiar CL characteristics and the presence of fluid inclusions 
suggests that hydrothermal zircon and thorite indeed precipitated from the aqueous hydrothermal fluid that generated the Sn-W mineralization in the Mole Granite. This stage of zircon crystallization, intimately associated with solidification of the Mole Granite is dated at $246.2 \pm 0.5 \mathrm{Ma}$ by hydrothermal xenotime (zircon did not provide a precise age; see Schaltegger et al., 2005).

(4) Zircon associated with biotite-dominated alteration zones crossing the granite was collected at the Paradise Lode (coordinates: GR 358.8E/6758.9N), a Sn and W-mineralized vein of $700 \mathrm{~m}$ length cutting through both seriate and porphyritic granite. A metasomatic biotite alteration selvage up to $30 \mathrm{~cm}$ thick envelops the southern end of the vein. This black rock is composed of ca. $90 \mathrm{vol} \%$ biotite, 4 vol\% fluorite, and 2 vol\% each of topaz, zircon and monazite. Zircon (up to $500 \mu \mathrm{m}$ long), monazite and topaz occur as inclusions in the larger biotite grains, and the zircon crystals are surrounded by a distinctive black halo. Zircon is much more abundant in the alteration halo than in the granite, indicating its metasomatic genesis by zirconium addition to the rock (compare Nesbitt et al., 1999). Cathodoluminescence images (Fig. 2f) generally reveal a core of regular oscillatory zonation, followed by a variably thick low-luminescent rim cutting the oscillatory growth zonation. U-Pb isotope geochemistry of this zircon indicates partial lead loss, hence no precise age could be obtained. Associated monazite interpreted to be of hydrothermal origin yields a concordant $\mathrm{U}-\mathrm{Pb}$ date of $244.4 \pm$ 1.4 Ma, postdating the solidification of the host granite by about 2 Myrs (Schaltegger et al., 2005).

\section{Analytical methods}

Zircon and thorite crystals were analyzed for their major to trace element chemistry by LA-ICPMS, with an emphasis on the petrographic control of the relative succession of mineral crystallization presented above. Inclusions in quartz were analyzed in bulk, while spot analysis (core and rim) was done on the larger exposed crystals from the Paradise lode. The advantage of analyzing quartzhosted zircon inclusions is twofold. Firstly, it allows for a better resolution of the relative growth history of zircon in a crystallizing magma according to the entrapment sequence; and secondly, inclusions are better shielded from postcrystallization modifications such as hydrothermal overprinting, and 
metamictization cannot induce selective element losses (e.g., radiogenic $\mathrm{Pb}$ ) through the host phenocryst.

Our LA-ICPMS setup consists of a pulsed $193 \mathrm{~nm}$ ArF Excimer laser (Lambda Physik, Germany) with a homogenized beam profile (Microlas, Germany) interfaced to an ELAN 6100 (Perkin Elmer, Canada) ICPMS (Günther et al., 1997). Machine parameters are summarized in Table 1, and details on the analytical procedure can be found in Pettke et al. (2004). Data reduction was done using LAMTRACE and in-house spreadsheets following methods described by Heinrich et al. (2003) and Halter et al. (2002). Bracketing external standardization was done on the certified SRM 610 silicate glass from the National Institute of Standards and Technology.

Internal standardization of the analyses is required to correct for differences in laser ablation efficiency between NBS 610 and the samples. This was done as follows. Ablation of an inclusion produces a signal consisting of a mixture of inclusion and host quartz evolving in unknown proportions with time (Fig. 3). These transient analyte signals were quantified via internal standardization to a total of $67.2 \mathrm{wt}$ \% element oxides, i.e., $100 \mathrm{wt} \%$ element oxides minus the stoichiometric $\mathrm{SiO}_{2}$ content of the zircon of $32.8 \mathrm{wt}$ - $\%$. This approach assumes that element contents in the quartz other than $\mathrm{SiO}_{2}$ do not contribute significantly to the zircon inclusion signal. The approach of using the total of element oxides to determine the relative sensitivity factor was evaluated by Leach and Hieftie (2000). They concluded that it is viable as long as all the elements significantly contributing to the total have been analyzed reliably. For the data set presented here, this is the case except for $\mathrm{P}_{2} \mathrm{O}_{5}$ that was not always analyzed, and $\mathrm{Si}$, which cannot be reliably quantified due to the dominant host quartz contribution. For quantification, a concentration value thus had to be assigned to these two elements, which fortunately share the same site in the crystal structure of zircon for the common case where incorporation of REE is dominantly by coupled xenotime-type substitution (Speer, 1982). Concentrations of $\mathrm{SiO}_{2}$ in zircon reported in the literature are usually between 27 and 33 wt- $\%$, those of $\mathrm{P}_{2} \mathrm{O}_{5}$ in synthetic runs never exceed 5 wt-\% (e.g., Hanchar et al., 2001). The composition of thorite was quantified accordingly to a total of 81 wt-\% element oxides (i.e. 100 wt-\% - stoichiometric $\mathrm{SiO}_{2}$ ). Monazite chemistry was quantified by normalizing to 
$80 \mathrm{wt}-\%$ element oxides (i.e., $100-20 \mathrm{wt}-\% \mathrm{P}_{2} \mathrm{O}_{5}$; average of 14 analyses in Schaltegger et al., 2005). The major contribution to the total uncertainty on the absolute element concentrations thus arises from the internal standardization. Our conservative estimate of the total uncertainty is $\pm 5 \%$ except where the analytical precision was limited by counting statistics for elements analyzed close to their limits of detection (LOD). This analytical uncertainty is rather large for major elements such as $\mathrm{ZrO}_{2}$, but compares well with uncertainties inherent in other microbeam techniques (e.g., Secondary Ion Mass Spectrometry; Hoskin, 1998).

In a second step, this mixed analyte signal was corrected for trace element contribution from the host quartz, based on the total Si signal from the inclusion plus host quartz interval. Only $\mathrm{Li}, \mathrm{Al}, \mathrm{P}, \mathrm{Sn}$ and $\mathrm{Bi}$ are present in the quartz at significant concentration levels relative to zircon, thorite and monazite $(17 \mu \mathrm{g} / \mathrm{g} \mathrm{Li}$, $150 \mu \mathrm{g} / \mathrm{g} \mathrm{Al}, 20 \mu \mathrm{g} / \mathrm{g} \mathrm{P}, 26 \mu \mathrm{g} / \mathrm{g}$ Sn and $0.04 \mu \mathrm{g} / \mathrm{g}$ Bi on average; Table 2).

Because the signal interval of the zircon inclusion was sometimes associated with a dominant quartz signal contribution (i.e., the mass of inclusion divided by the total mass ablated was often $<0.2$ ), the concentrations of $\mathrm{Li}, \mathrm{Sn}$ and $\mathrm{Bi}$ in zircon and thorite may have uncertainties of up to $\pm 50 \%$ in the worst case.

Limits of detection were calculated for each element and analysis individually as three times the standard deviation of the background signal (taken before laser ablation) divided by element sensitivity during the respective ablation. For nonsignificant analyte signals, LOD values are reported in Tables 2 and 3, marked by $<$ LOD. The smaller the inclusions are (i.e., the smaller the chosen pit size was), the higher the resulting LOD will be for a given element since the background signal remains the same while the amount of mass ablated per unit time decreases roughly by the square of the radius of the pit size. This only applies in such a predictable way for laser systems with a homogeneous energy density across the ablation pit. Additionally, pure quartz essentially dilutes the analytical signal of zircon measured as inclusions, thereby reducing the sensitivity of all elements in the zircon signal. Therefore, LODs were about a factor of 5 higher than for direct mineral analysis, so that only the minimal size of the negative Euanomaly (Table 3) could be determined for some zircon inclusions.

The total $\mathrm{Pb}$ content of some hydrothermal zircon and thorite inclusions was determined by analyzing all isotopes of $\mathrm{Pb}$ and summing them up. The total signal 
obtained on mass 204 was strongly dominated by ${ }^{204} \mathrm{Hg}$ (estimated from ${ }^{202} \mathrm{Hg} /{ }^{204} \mathrm{Hg}=4.35$; Rosman and Taylor, 1998), hence the ${ }^{204} \mathrm{~Pb}$ concentrations in the hydrothermal zircon crystals are only known to be below $\sim 1 \mu \mathrm{g} / \mathrm{g}$. This translates to initial $\mathrm{Pb}$ concentrations of a few tens of $\mu \mathrm{g} / \mathrm{g}$ of $\mathrm{Pb}$ as an upper limit (assuming common $\mathrm{Pb}$ isotopic compositions). A more reliable way of estimating the initial $\mathrm{Pb}$ content in the present case is to subtract the in-situ growth contribution from the decay of $U$ and Th during $247 \mathrm{Ma}$ (Schaltegger et al., 2005). This way, the common $\mathrm{Pb}$ content was calculated to be not different from zero (permitting for $5 \%$ total analytical uncertainty on $\mathrm{U}$, Th and $\mathrm{Pb}$ ) in all cases but one, where the concentration of initial $\mathrm{Pb}$ resulted in $34 \mu \mathrm{g} / \mathrm{g}$. This analysis ( $m \_03 a 15$ in Table 3) is interpreted to reveal a Pb-rich fluid or mineral inclusion within the zircon grain and is thus not considered further.

It is important to understand, finally, that the method of internal standardization applies the same relative sensitivity factor to all the elements in one analysis, hence the ratios between the various elements remain unaffected by internal standardization. Therefore, element ratios in the sample are uniquely determined by the use of external standardization only. This implies that the shape of the chondrite-normalized REE patterns, for example, are insensitive to the type of internal standardization applied; internal standardization only affects the absolute concentrations of all the elements, to the same extent, within a single analysis.

\section{Results}

Measurements were recorded as raw data in time-resolved mode (Fig. 3), enabling partial resolution of small-scale chemical heterogeneities within grains such as chemical zonation between core and rim sections of the included crystal (e.g., $\mathrm{U} / \mathrm{Hf}$ in Fig. 3a) or the presence of tiny inclusions not necessarily visible with a petrographic microscope (Fig. $3 b$ ). In such cases, only sections of signals corresponding to inclusion-free zones or to core or rim sections of included grains were integrated (marked as "core interval" or "rim interval" in Table 3). This has proven to be essential, because the majority of analyzed zircon grains showed signal evidence for inclusions - elevated signals of $\mathrm{Na}$ are characteristic for fluid inclusions, the presence of mineral or melt inclusions was revealed by $\mathrm{Al}, \mathrm{K}_{2} \mathrm{O}, \mathrm{Sn}$ or Ce. Such splitting of signals does not provide pure core or rim compositions of 
grains but, as shown below, chemical trends with progressive zircon crystallization are well resolved. The results for zircon and thorite analyses free from inclusion contamination are reported in Table 3.

Trace element concentrations in zircon generally decrease from early magmatic to hydrothermal zircon, except for $\mathrm{Li}$, Ta and, to a lesser extent, Sn (Fig. 4a,b,c). All chondrite (McDonough and Sun, 1995) normalized REE patterns of zircon are steep and HREE-enriched. The HREE enrichments ( $\leq 75000$-times chondritic) in early magmatic zircon of the Yankee Lodes are exceptional, exceeding examples from the literature for gabbros to granites, ophiolites, charnokites, carbonatite and kimberlite (e.g. Hoskin and Ireland, 2000; Hoskin et al., 2000), of alkaline rocks (Hinton and Upton, 1991), of high-grade metamorphic rocks (e.g. Barbey et al., 1995; Bea, 1996, Rubatto, 2002), and even zircon of hydrothermal origin (Hoskin et al., 1998). Only zircon inclusions in corundum (Guo et al., 1996) showed similar HREE enrichments and trace element concentrations. The REE patterns show a strong negative Eu anomaly and a variably positive $\mathrm{Ce}$ anomaly that becomes more and more positive from early magmatic to hydrothermal zircon in the Yankee Lodes samples (Fig. 4). The steepness of the REE patterns increases from early magmatic to hydrothermal zircon, from $\mathrm{La}_{N} / \mathrm{Lu}_{N} \sim 3.5 * 10^{-3}$ to values as low as 3 * $10^{-5}$. Heavy REE and MREE enrichments are uniform throughout. The degree of LREE depletion positively correlates with the size of the positive Ce-anomaly that is most pronounced for hydrothermal zircon. Concentration plots of $\mathrm{HfO}_{2} / \mathrm{Y}_{2} \mathrm{O}_{3}$ vs. $\mathrm{ZrO}_{2} / \mathrm{Y}_{2} \mathrm{O}_{3}$ or $\mathrm{Ta} / \mathrm{Nb}$ vs. $\mathrm{ZrO}_{2} / \mathrm{Y}_{2} \mathrm{O}_{3}$ (Fig. 5) show correlations between distinctive clusters for each of the petrographic groups. A more detailed presentation of the results follows, grouped according to the petrographic types of zircon.

\section{(1) Early magmatic zircon: sample "vnlt"}

Trace element contents (Table 3) are fairly uniform and decrease conspicuously from core to rim while only $\mathrm{ZrO}_{2}$ distinctly increases from 47 to $60 \mathrm{wt}-\%$. $\mathrm{HfO}_{2}$ remains essentially constant around $1.4 \mathrm{wt} \%$. Chondrite-normalized REE patterns are HREE-enriched and show $\mathrm{Yb}>\mathrm{Lu}$ where $\mathrm{Yb}$ is up to 75000 times chondritic (Fig. 4a). A pronounced negative Eu anomaly of $\sim 0.026$ is developed, while there is virtually no anomaly for $\mathrm{Ce}\left(\mathrm{Ce} / \mathrm{Ce}^{*} \sim 1.2\right)$. Thorium/uranium ratios are fairly uniform between 0.34 and 0.48 and much lower than the Th/U ratio of ca. 2.5 of 
the bulk rock (Audétat, 1999), with concentrations of 0.7 to $1.4 \mathrm{wt}-\% \mathrm{UO}_{2}$; these ratios are also lower than those typical for igneous zircon (e.g., Hoskin and Schaltegger, 2003). Early magmatic zircon is characterized by low $\mathrm{Hf} / \mathrm{Y}, \mathrm{Zr} / \mathrm{Y}$ and $\mathrm{Ta} / \mathrm{Nb}$ ratios (Fig. 5).

Zircon - melt distribution coefficients calculated from averages of early magmatic zircon $(n=4)$ Mole Granite $(n=14)$ bulk rocks are provided in Table 4. Hafnium, Nb, Sn, Th, U, Y and the REE all partition in favor of zircon.

\section{(2a) Late magmatic zircon: Yankee Lode}

Strongly variable trace element contents characterize this petrographic type of zircon, and the concentrations are generally lower than those of the early magmatic zircon. The decrease of trace element contents from core to rim intervals is conspicuous. Late magmatic zircon crystals are essentially devoid of $\mathrm{FeO}$ and have much more uniform $\mathrm{Y}_{2} \mathrm{O}_{3}$ and $\mathrm{ZrO}_{2}$ concentrations (around 1 and 60 wt-\%, respectively; Table 3 ). $\mathrm{HfO}_{2}$ tends to be elevated with respect to early magmatic zircon. Chondrite-normalized REE patterns (Fig. 4b) show Yb $\leq$ Lu where Lu is up to 32000 times chondritic. Heavy REE and MREE values vary up to one order of magnitude, while those of the LREE vary almost three orders of magnitude. The negative Eu anomaly is of the same magnitude as that of the early magmatic zircon. The positive $\mathrm{Ce}$ anomaly is conspicuously evolving from $\mathrm{Ce} / \mathrm{Ce}$ * $\sim 1.3$ (core intervals) to values as high as 38 (rim intervals; Table 3).

Thorium/uranium ratios vary between 0.13 and 0.80 , with concentrations of $\mathrm{UO}_{2}$ varying between 0.11 and $1.76 \mathrm{wt}-\%$, those of $\mathrm{ThO}_{2}$ between 0.05 and $1.18 \mathrm{wt}$ \% . In element correlation plots $\left(\mathrm{HfO}_{2} / \mathrm{Y}_{2} \mathrm{O}_{3}\right.$ vs. $\mathrm{ZrO}_{2} / \mathrm{Y}_{2} \mathrm{O}_{3}$ or $\mathrm{Ta} / \mathrm{Nb}$ vs. $\mathrm{ZrO}_{2} / \mathrm{Y}_{2} \mathrm{O}_{3}$; Fig. 5) late magmatic zircon crystals always plot in between early magmatic and hydrothermal zircon.

\section{(2b) Late magmatic monazite: Yankee Lode}

Monazite coexisting with zircon and thorite as inclusions in quartz crystals are characterized by steep chondrite-normalized REE patterns (Fig. 4e) strongly enriched in LREE (La is up to 530000 times chondritic). They are essentially devoid of a Ce-anomaly but have a pronounced negative Eu-anomaly $\left(\mathrm{Eu} / \mathrm{Eu}^{*} \cong\right.$ 0.005). This pattern is closely comparable to that obtained on the monazite 
separated from the rock matrix by Schaltegger et al. (2005) but somewhat steeper $\left(\mathrm{La}_{N} / \mathrm{Lu}_{\mathrm{N}} \leq 780\right)$. Concentrations of $\mathrm{Y}_{2} \mathrm{O}_{3}$ are between 1.1 and $1.5 \mathrm{wt}-\%$, those of $\mathrm{ThO}_{2}$ and $\mathrm{UO}_{2}$ are variable between $15-30$ and $0.25-0.51$, respectively, while the $\mathrm{ThO}_{2} / \mathrm{UO}_{2}$ ratios are fairly uniform between 51 and 75 . This is much higher than that found for whole monazite grains from the matrix by isotope dilution (Schaltegger et al., 2005), reflecting a conspicuously high $\mathrm{ThO}_{2}$ content that may be characteristic for earlier crystallized monazite inclusions in quartz phenocrysts (i.e., prior to crystallization of thorite, see below). Other trace elements (Table 3) are generally below a few tens of $\mu \mathrm{g} / \mathrm{g}$ concentration levels.

\section{(3) Hydrothermal zircon: Yankee Lode}

Hydrothermal zircon shows overall lower trace element abundances than both magmatic types. Concentrations of $\mathrm{Y}_{2} \mathrm{O}_{3}$ are below 0.67 and $\mathrm{Fe}$ contents are usually below a few hundred $\mu \mathrm{g} / \mathrm{g}$. $\mathrm{ZrO}_{2}$ exceeds $60 \mathrm{wt}-\%$, and $\mathrm{HfO}_{2}$ concentrations are highest in hydrothermal zircon, between 1.51 and $4.30 \mathrm{wt} \%$. $\mathrm{P}_{2} \mathrm{O}_{5}$ values are low, between 0.15 and $0.29 \mathrm{wt}-\%$. Values for $\mathrm{Sn}$ tend to be elevated in hydrothermal zircon when compared to magmatic zircon. Chondritenormalized REE patterns (Fig. 4c) show $Y b<L u$ where $L u$ is up to 23000 times chondritic. Chondrite-normalized HREE and MREE values vary less than about a factor of 5, while those of the LREE vary somewhat more than an order of magnitude. Again, Eu was not always detected, but the extent of the negative Eu anomaly appears to be similar to that documented for the magmatic zircon populations. The positive Ce anomaly is variable between 2.7 and 18.6, with two much higher values, 39 and 45 (Table 3). Ta/Nb ratios are distinctly elevated with respect to magmatic zircon. Th/U ratios are between 0.06 and 0.28 , lower than those of magmatic zircon, as are concentrations of $U$ and Th $\left(0.13<\mathrm{UO}_{2}<0.72\right.$ wt-\%; $0.01<\mathrm{ThO}_{2}<0.13$ wt-\%). Similarly low $\mathrm{Th} / \mathrm{U}$ ratios were reported for hydrothermal zircon from massive sulfide deposits of the Iberian Pyrite Belt (Nesbitt et al., 1999).

Partition coefficients between hydrothermal zircon and hydrothermal fluid of the Yankee Lodes are provided in Table 5 for $\mathrm{Li}, \mathrm{Sn}, \mathrm{Cs}, \mathrm{Ce}, \mathrm{Pb}$ and $\mathrm{Bi}$. Fluid compositions were determined by LA-ICPMS on pseudosecondary inclusion assemblages that start from the same primary growth zone where zircon crystals 
were included. Only Ce partitions in favor of zircon. The other trace elements can be grouped into elements that are slightly incompatible ( $\mathrm{Li}, \mathrm{Sn}, \mathrm{Bi}$ ) and strongly incompatible ( $\mathrm{Cs}$ and $\mathrm{Pb})$ in hydrothermal zircon.

\section{Late magmatic (2) and hydrothermal (3) thorite: Yankee Lode}

Brown thorite shows markedly different REE contents and chondrite normalized patterns (Fig. 4d) when compared to those of zircon and monazite. REE contents $\left(0.56\right.$ wt- $\% \leq \sum_{\text {REE-oxides }} \leq 1.56$ wt- $\left.\%\right)$ are variable and comparable to those in early magmatic zircon but show an upward convex spectrum documenting strong MREE and some HREE enrichment $\left(0.040 \leq \mathrm{La}_{\mathrm{N}} / \mathrm{Dy}_{\mathrm{N}} \leq 0.007\right.$ and $0.086 \leq \mathrm{La} \mathrm{a}_{\mathrm{N}} / \mathrm{Lu}_{\mathrm{N}} \leq$ 0.013 , respectively). Thorium/uranium ratios are between 2.1 and 4.7 . The REE patterns show a pronounced negative Eu-anomaly $\left(0.0232>\mathrm{Eu} / \mathrm{Eu}^{*}>0.0008\right)$ and a slight positive $\mathrm{Ce}$ anomaly $\left(1.63>\mathrm{Ce} / \mathrm{Ce}^{*}>1.18\right)$. Trace element patterns are indistinguishable for late-magmatic and hydrothermal thorite.

\section{(4) Hydrothermal zircon: Paradise Lode}

Crystallization of hydrothermal zircon associated with biotite-rich hydrothermal alteration at the Paradise Lode postdates the crystallization of the host granite by ca. 2 Myrs (Schaltegger et al., 2005). Paradise Lode zircon is characterized by trace element concentrations that increase by up to a factor of 50 from core to rim, opposite to the trend documented above for early magmatic to hydrothermal zircon from the Yankee Lodes. Chondrite-normalized REE patterns (Fig. 6) are HREE enriched ( $\mathrm{Lu} \leq 36000$ times chondritic) and become flatter from core to rim sections $\left(0.005 \geq \mathrm{La}_{N} / \mathrm{Lu}_{\mathrm{N}} \geq 0.037\right)$. Core sections have $\mathrm{ZrO}_{2}$ and $\mathrm{Y}_{2} \mathrm{O}_{3}$ concentrations around 64.5 and 0.3 wt- $\%$, respectively, and $\mathrm{HfO}_{2}$ concentrations are around $1.3 \mathrm{wt}-\%$. Rim sections have lower contents of $\mathrm{ZrO}_{2}$ ( $\sim 55.7$ wt-\%) but higher $\mathrm{Y}_{2} \mathrm{O}_{3}$ and $\mathrm{HfO}_{2}$ (up to 2.5 and 3.5 wt-\%, respectively). $\mathrm{ZrO}_{2} / \mathrm{Y}_{2} \mathrm{O}_{3}$ ratios decrease from core to rim while $\mathrm{Ta} / \mathrm{Nb}$ ratios remain uniform (Fig. $5 b$ ). Sn values are also elevated in rim relative to core zones. Thorium and $U$ concentrations of core sections are lower than magmatic values reported above, and $\mathrm{Th} / \mathrm{U}$ ratios are around 0.35 . Rim sections are characterized by much higher Th and $U$ concentrations and lower Th/U ratios that approach 0.15 . The pronounced 
negative Eu anomaly and the weak positive Ce anomaly are uniform for core and rim sections at about 0.07 and 1.5 , respectively.

\section{Discussion}

The first and most important finding of the present study is the considerable variability of zircon trace element chemistry that relates to the stage at which zircon crystallized from a progressively evolving felsic magma and related hydrothermal fluids. The zircon chemistry appears to be highly sensitive to the physico-chemical environment in which zircon crystallized, in obvious contrast with the conclusions drawn by Hoskin and Ireland (2000). Trace element incorporation into early magmatic zircon, interpreted to have crystallized at a deep crustal level, exceeded $10 \mathrm{wt}$ \% total element oxides, hence was apparently never limited by the incorporation of charge-compensating elements (cf. Hanchar et al., 2001; Finch et al., 2001). Checking for charge balance assuming that the xenotime-type substitution (eqn 1 above) dominates trace element incorporation into zircon, the molar sum of $(\mathrm{Y} \text { and } \mathrm{REE})^{3+}$ exceeds that of $(\mathrm{P}+\mathrm{Nb}+\mathrm{Ta})^{5+}$ by a factor of 1.5 to 1.9 (10 out of 11 analyses where $P$ analyses are available; Table 3), consistent with observations in both natural and synthetic occurrences (e.g., Speer, 1982; Hinton and Upton, 1991; Hanchar et al, 2001). Assuming that interstitial $\mathrm{Li}\left(\mathrm{Li}^{+}=0.60 \AA\right)$ accounts for charge balance of the excess $(Y+R E E)$ we find that only one zircon grain contains more $\mathrm{Li}$ than required for charge balance (shot m_02a16; Table 3), the other zircon grains are approaching charge neutrality (permitting for up to $50 \%$ analytical uncertainty on Li due to the often high correction for Li contributed by the host quartz) or still preserve a charge deficit. It can further be speculated that interstitial $\mathrm{Al}, \mathrm{Fe}$ and possibly Mg (not analyzed) may account for charge balance in early magmatic zircon (Hoskin et al., 2000) as Al and Fe are strongly enriched (sample vnlt; Table 3). Other possibilities to obtaining charge balance include the incorporation of $\mathrm{H}^{+}$or $(\mathrm{OH})^{-}$or the protonation of the $\mathrm{O}^{2-}$ ions of the $(\mathrm{SiO} 4)^{4-}$ groups, but our data do not allow to address these issues. The interested reader is referred to Finch and Hanchar (2003) and Hoskin and Schaltegger (2003) for a detailed summary of the current knowledge of trace element incorporation into zircon. 
The extreme HREE enrichments ( $\leq 75000$-times chondritic) in early magmatic zircon of the Mole Granite suggests that it crystallized as the first major REE acceptor from a felsic melt that was either depleted in Eu possibly by earlier feldspar-fractionation, or it reflects an inherited source signature. The combination of zircon, monazite and xenotime U-Pb geochronology (Schaltegger et al., 2005) with the trace-element geochemistry reported here suggests that Stages $A$ and $B$ of zircon growth and magmatic monazite crystallization occurred at $246.7 \pm 0.5 \mathrm{Ma}$ during the early magma crystallization and differentiation, probably in the lower crust or during ascent of the magma, but about 1.4 Ma prior to magma emplacement in the present sill-shaped intrusion of the Mole Granite. Uppercrustal emplacement, bulk crystallization, fluid exsolution and high-temperature quartz-cassiterite mineralization are interpreted to have all occurred within a very short period near $246.2 \pm 0.5 \mathrm{Ma}$. This date is recorded by hydrothermal xenotime, which precipitated from high-temperature magmatic fluids together with vein quartz and zircon crystals of Stage $D$, slightly before cassiterite saturation due to mixing of the magmatic fluids with meteoric water (Audétat et al., 1998, 2000). The latemagmatic zircon growth of Stage $C$ as defined in Schaltegger et al. (2005) may be coeval with the emplacement and in-situ crystallization of the alkali feldspar granite, but neither of these two later zircon generations could be directly dated at a useful precision.

The evolution of the REE patterns of the successive zircon populations can be used as a monitor of the physico-chemical changes of the residual melt and the fluid that exsolved with progressive crystallization. The trends in the REE patterns for the Yankee Lodes (schematically shown in Fig. 7a) show an overall REE depletion from early magmatic to hydrothermal stages, most pronounced for the LREE, together with a growing positive Ce-anomaly. It monitors the successive stabilization of different sinks for REE in the magma with progressive fractionation. The progressive depletion in LREE observed for the magmatic zircon stages reflects the concurrent crystallization of monazite (Fig. 4e) and possibly apatite while the less pronounced depletion of MREE and HREE can be ascribed to growth of thorite (Fig. 4d). The exsolution of an aqueous fluid phase late in the crystallization history may provide an additional sink for REE. Reed et al. (2000) have shown experimentally $\left(800^{\circ} \mathrm{C}\right.$ and $200 \mathrm{MPa}$ ) for the partitioning of REE 
between a peraluminous monzogranitic melt and a Cl-bearing, S- and C-free aqueous fluid that the LREE were distributed more into the aqueous fluid than were the HREE, and that the concentrations of REE in the aqueous fluid phase increased with the total chlorine concentration in the fluid relative to those in the felsic melt. The REE pattern of a fluid is thus enriched in LREE relative to that of the coexisting silicate melt. For an aqueous fluid with a $\mathrm{Cl}^{-}$concentration of $3.5 \mathrm{~m}$, corresponding to a total salinity of ca. $20 \mathrm{wt}-\% \mathrm{NaCl}_{\text {equiv }}$ fluid/melt distribution coefficients were $>1$ for LREE, and between 0.5 and 0.8 for HREE. The aqueous fluid in equilibrium with the residual melt in the Mole Granite had a bulk salinity of about $5 \mathrm{wt}-\% \mathrm{NaCl}_{\text {equiv }}$ only (Audétat et al., 2000b), hence the exsolved fluid phase was most probably poorer in REE relative to the residual melt. It is therefore concluded that the REE patterns of magmatic zircon that crystallized first in absence, then in presence, of an aqueous fluid phase reflect the effects of concomitant crystallization of other accessory minerals, namely monazite, thorite and possibly apatite, and that the effect of the exsolution of an aqueous fluid was clearly subordinate.

Hydrothermal zircon crystals thus have REE patterns that are very similar to those of the late-magmatic zircon crystals (Fig. 4b,c), while the $\mathrm{Ta} / \mathrm{Nb}$ ratio resolves these populations (Fig. 5). The work of Reed et al. (2000) discussed above infers that the REE signature of the magmatic-hydrothermal fluid from which the hydrothermal zircon crystals precipitated is also very similar to that of the parental silicate melt from which the fluid exsolved. This in turn suggests that the distribution coefficients of REE between zircon and an aqueous fluid are likely to be similar to those between zircon and a granitic silicate melt, implying that the REE patterns cannot resolve whether zircon crystallized from a silicic melt or from a magmatic-hydrothermal fluid derived from it. A suite of zircon populations crystallized during progressive stages in an evolving magma including associated magmatic-hydrothermal stages will thus have REE characteristics and other trace element patterns that are most prominently influenced by the co-precipitation of other REE and trace-element accepting minerals, usually accessory minerals.

The prominent positive $\mathrm{Ce}$ anomaly that evolves from late magmatic to hydrothermal zircon is an exception from the above rule, however. This anomaly becomes larger with progressive fractionation and likely monitors a relative 
increase of $\mathrm{Ce}^{4+}$ in the melt and in the magmatic fluid from which zircon precipitated, suggesting an increase in $\mathrm{f}_{\mathrm{O} 2}$ (compare Ballard et al., 2002). The strong preference of $\mathrm{Ce}$ for hydrothermal zircon relative to the aqueous fluid phase is demonstrated by its distribution coefficient, $\mathrm{D}\left(\mathrm{Ce}_{\mathrm{zrn}} / \mathrm{Ce}_{\text {fluid }}\right) \approx 14$ (Table 5 ), at an average Ce content of the fluid of $0.9 \mu \mathrm{g} / \mathrm{g}$ (Audétat, 1999). Note that the effect of coeval growth of monazite (apparently severely depleting the fluid with respect to its overall Ce content) was subordinate to that of increasing the oxidation state of the remaining $\mathrm{Ce}$ to $\mathrm{Ce}^{4+}$, underscoring the importance of ionic radii and charge for the incorporation of trace elements into zircon.

Element distribution coefficients between zircon and hydrothermal fluid (Li, Sn $\mathrm{Cs}, \mathrm{Ce}, \mathrm{Pb}, \mathrm{Bi}$; Table 5) reveal that only Ce partitions in favor of zircon, most likely because of $\mathrm{Ce}^{4+}$ as outlined above. Similarly, $\mathrm{Sn}$ may occur both as a tetravalent or bivalent cation, where the latter appears to be important in solutions as $\mathrm{Sn}^{2+}$ halogen or hydroxychloro complexes (Heinrich, 1990). Incorporation of Sn into hydrothermal zircon therefore depends not only on its concentration in the solution but also on the redox state of the fluid. For $\mathrm{Sn}^{4+}$ (ionic radius $0.71 \AA$ ), incorporation into zircon onto the $\mathrm{Zr}^{4+}$ site (ionic radius $0.80 \AA$ ) requires no charge balance, and $\mathrm{Sn}^{4+}$ fits the zircon structure as opposed to $\mathrm{Sn}^{2+}$ (ionic radius $1.12 \AA$ ).

Lead and Cs are strongly incompatible in hydrothermal zircon as could be expected from their large ion size and the lattice strain theory (e.g., Finch et al., 2001). Common $\mathrm{Pb}$ contents of the analyzed hydrothermal zircon (estimated from the analyzed total U-Th-Pb contents (Table 3) corrected for in-situ grown $\mathrm{Pb}$ since $247 \mathrm{Ma}$ ) do not exceed $2 \mu \mathrm{g} / \mathrm{g}$ for most bulk zircon analyses. With an average $\mathrm{Pb}$ content of the hydrothermal fluid of $\sim 2500 \mu \mathrm{g} / \mathrm{g}$ (Audétat, 1999), the resulting distribution coefficient $\mathrm{D}\left(\mathrm{Pb}_{\mathrm{zr}} / \mathrm{Pb}_{\text {fluid }}\right)$ is $<0.001$ (Table 5), more than two orders of magnitude lower than that reported for zircon grown experimentally from $\mathrm{Pb}$-rich solutions (Watson et al., 1997). Obviously, not all hydrothermally grown zircon crystals are characterized by high common $\mathrm{Pb}$ contents. Similarly, $\mathrm{D}\left(\mathrm{Cs}_{\mathrm{zm}} / \mathrm{Cs}_{\text {fluid }}\right)$ is also of the order of 0.001 (average fluid $=3000 \mu \mathrm{g} / \mathrm{g}$; Audétat, 1999). Moreover, the zircon - fluid distribution coefficients reported here should be regarded as maximum estimates - even submicroscopic fluid inclusions in the zircon with thousands of $\mu \mathrm{g} / \mathrm{g} \mathrm{Pb}$ and $\mathrm{Cs}$ would dominate the bulk zircon Pb and Cs contents, 
hence true distribution coefficients could even be much smaller than 0.001 for hydrothermal zircon.

\section{Hydrothermal zircon from the Paradise Lode}

Zircon from the metasomatic biotite selvage around the Paradise Lode reveals chondrite-normalized REE patterns that show higher REE contents for rim sections relative to its core (Figs. 6, 7b), i.e., opposite to the trends documented for Yankee Lodes zircon but closely comparable to trends reported between magmatic and hydrothermal zircon from the Boggy Plain Pluton (Hoskin et al., 1998; Fig. 7c). This demonstrates that REE patterns, by themselves, do not allow genetic inferences for zircon. Precise $\mathrm{U}-\mathrm{Pb}$ zircon and monazite ages reveal that metasomatism at Paradise Lode postdates the solidification of the host Mole Granite by ca. 2 Myrs (Schaltegger et al., 2005). Zircon crystals of the Paradise Lode, therefore, cannot represent the product of simple progressive melt fractionation, fluid exsolution and hydrothermal precipitation in the shallow-crustal environment of the Mole Granite, as in the case of the Yankee Lodes zircon crystals (see above). The combined evidence of different trends in REE patterns from core to rim and the different age of these zircon crystals when compared to those of the Yankee Lode reveals that they crystallized from an independent, later fluid source of different composition that probably evolved from a hidden intrusion unrelated to the Mole Granite.

\section{Chemical characteristics of hydrothermal zircon}

A variety of sometimes contradictory statements about what is characteristic for hydrothermal zircon is dispersed in the literature (e.g., Claoué-Long et al., 1990; Rubin et al., 1993; Yeats et al., 1996; Hoskin et al., 1998; Nesbitt et al., 1999). In itself, this might suggest that not all zircon occurrences claimed to be hydrothermal in origin indeed crystallized from an aqueous fluid. However, the two contrasting examples of hydrothermal zircon shown here reveal that there is no set of chemical criteria allowing unequivocal distinction between hydrothermal and magmatic zircon (Fig. 7). Variations in trace element abundances and chondritenormalized REE patterns are much larger for different occurrences of genetically similar zircon when compared to genetically different zircon from one occurrence, 
notably for the hydrothermal environment. Findings on hydrothermal zircon from the Boggy Plain Pluton (Hoskin et al., 1998) cannot be considered universally valid. For hydrothermal zircon, the following statements may have a broader applicability and warrant more extensive testing: (1) Our estimated partition coefficients between zircon and fluid are low for $\mathrm{Pb}$, hence hydrothermal zircon is not necessarily characterized by elevated common $\mathrm{Pb}$ contents as suggested in the literature unless such zircon crystallized from hydrothermal solutions extremely enriched in $\mathrm{Pb}$ (magmatic-hydrothermal fluids may contain up to $10000 \mu \mathrm{g} / \mathrm{g} \mathrm{Pb}$ ); and (2) partition coefficients are higher for Li and Sn, because Li may serve as an interstitial charge-compensating element and $\mathrm{Sn}^{4+}$ can fit reasonably well into the $\mathrm{Zr}^{4+}$ site. Redox potentials evolving from magmatic to hydrothermal conditions affect the distribution coefficient of some trace elements between fluid and melt in response to changes in ionic size and charge. Elevated Ce and Sn contents $\left(\mathrm{Ce}^{4+}\right.$ and $\mathrm{Sn}^{4+}$ ) could thus be characteristic for hydrothermal zircon from magmatichydrothermal fluids, pointing to a relatively elevated oxygen fugacity.

\section{Conclusions}

Trace element chemistry data differ significantly between zircon assemblages that grew at different stages and in different chemical environments of the crystallizing Mole Granite magma and associated Sn-W-rich hydrothermal veins. Differences include absolute contents of trace elements, evolving REE patterns, extent of the negative $\mathrm{Eu}$ and positive Ce-anomalies and selected trace element ratios, notably $\mathrm{Nb} / \mathrm{Ta}$ and $\mathrm{Th} / \mathrm{U}$ ratios. This chemical variability of zircon directly reflects chemical diversity of the melt or the fluid from which the zircon precipitated. However, comparison with literature data reveals that the diversity of trace element characteristics of genetically similar zircon populations from different localities exceeds that observed between genetically different types of zircon from one locality. This is well illustrated here for zircon precipitated from hydrothermal fluids. Therefore, the trace element characteristics of zircon alone are not indicative for the magmatic versus hydrothermal origin of a given population of zircon.

Zircon may prove very useful in tracing the physico-chemical evolution with progressive crystallization, because zircon is often a liquidus phase and can 
crystallize throughout the protracted magmatic to hydrothermal evolution of an intrusion. The example of the Mole Granite magma has revealed a few early zircon crystals enclosed in quartz phenocrysts highly enriched in trace elements, possibly monitoring crystallization as a liquidus phase deep in the crust. Such high trace element contents might thus be characteristic for high-pressure magmatic crystallization. Late magmatic and magmatic-hydrothermal zircon crystals are characterized by very similar REE patterns. The effect of co-crystallization of other accessory minerals, including thorite, monazite, xenotime and possibly apatite dominates in this case over the subtle differences in fractionation between zircon and the silicate melt and its coexisting hydrothermal fluid with respect to the REE. Hydrothermal fluids liberated at different stages of magma crystallization or during metamorphic devolatilization can thus be expected to have highly variable trace element contents. Zircon crystals precipitated from such diverse fluid types will thus also have variable trace element characteristics, in line with the few apparently contrasting literature data on trace element contents in hydrothermal zircon.

The following characteristics may nevertheless be generally applicable to hydrothermal zircon: (1) Distribution coefficients of $\mathrm{Pb}$ between aqueous fluids and zircon are very small, $<0.001$ in the present case. Nevertheless, common $\mathrm{Pb}$ concentrations of hydrothermal zircon can be expected to vary significantly in response to strongly variable fluid $\mathrm{Pb}$ concentrations, e.g., magmatic-hydrothermal fluids with thousands of $\mu \mathrm{g} / \mathrm{g} \mathrm{Pb}$ or mesothermal Au-forming fluids with a few $\mu \mathrm{g} / \mathrm{g}$ $\mathrm{Pb}$ only. (2) Redox conditions in the hydrothermal environment are likely to be different from those prevailing at magmatic conditions. Oxygen fugacities of magmatic-hydrothermal fluids for example are commonly higher that those in the source magma from which the fluid exsolved, hence hydrothermal zircon will be enriched in trace elements that may occur in $4^{+}$valence (Ce and $\mathrm{Sn}$ in the present case). (3) Zircon may be enriched in $\mathrm{H}^{+}$(not analyzed in the present study) to achieve charge balance, and this may be one of possibly few remaining general criteria for identifying zircon precipitated from hydrothermal solutions.

\section{Acknowledgments}


We appreciate the help with the cathodoluminescence work by Karsten Kunze and Marianne Landtwing. The constructive review by J. Hanchar, and the comments by an anonymous referee, helped to balance our conclusions. Support to all four authors by the Swiss National Science Foundation is acknowledged. 


\section{References}

Aja, S.U., Wood, S.A. and Williams-Jones, A.E., 1995. The aqueous geochemistry of $\mathrm{Zr}$ and the solubility of some $\mathrm{Zr}$ - bearing minerals. Applied Geochemistry, 10(6): 603-620.

Alderton, D.H.M., Pearce, J.A. and Potts, P.J., 1980. Rare-earth element mobility during granite alteration - evidence from southwest England. Earth and Planetary Science Letters, 49(1): 149-165.

Audétat, A., 1999. The magmatic-hydrothermal evolution of the Sn/W-mineralized Mole Granite (Eastern Australia). PhD thesis, ETH Zurich: Nr.13168.

Audétat, A., Günther, D. and Heinrich, C.A., 1998. Formation of a magmatichydrothermal ore deposit: Insights with LA-ICP-MS analysis of fluid inclusions. Science, 279(5359): 2091-2094.

Audétat, A., Günther, D. and Heinrich, C.A., 2000a. Magmatic-hydrothermal evolution in a fractionating granite: A microchemical study of the Sn-W-Fmineralized Mole Granite (Australia). Geochimica et Cosmochimica Acta, 64(19): 3373-3393.

Audétat, A., Günther, D. and Heinrich, C.A., 2000b. Causes for large-scale metal zonation around mineralized plutons: Fluid inclusion LA-ICP-MS evidence from the Mole Granite, Australia. Economic Geology, 95(8): 1563-1581.

Ballard, J.R., Palin, J.M. and Campbell, I.H., 2002. Relative oxidation states of magmas inferred from $\mathrm{Ce}(\mathrm{IV}) / \mathrm{Ce}(\mathrm{III})$ in zircon: application to porphyry copper deposits of northern Chile. Contributions to Mineralogy and Petrology, 144(3): 347-364.

Banks, D.A., Yardley, B.W.D., Campbell, A.R. and Jarvis, K.E., 1994. REE composition of an aqueous magmatic fluid - a fluid inclusion study from the Capitan Pluton, New-Mexico, USA. Chemical Geology, 113(3-4): 259-272.

Barbey, P., Alle, P., Brouand, M. and Albarede, F., 1995. Rare-earth patterns in zircons from the Manaslu Granite and Tibetan slab migmatites (Himalaya) insights in the origin and evolution of a crustally-derived granite magma. Chemical Geology, 125(1-2): 1-17. 
Bea, F., 1996. Residence of REE, $Y$, Th and $U$ in granites and crustal protoliths; Implications for the chemistry of crustal melts. Journal of Petrology, 37(3): 521552.

Claoué-Long, J.C., King, R.W. and Kerrich, R., 1990. Archean hydrothermal zircon in the Abitibi Greenstone-Belt - constraints on the timing of gold mineralization. Earth and Planetary Science Letters, 98(1): 109-128.

Claoué-Long, J.C., King, R.W. and Kerrich, R., 1992. Reply to comment by F. Corfu and D.W. Davis on "Archaean hydrothermal zircon in the Abitibi greenstone belt: constraints on the timing of gold mineralization". Earth and Planetary Science Letters, 109: 601-609.

Condie, K.C., 1978. Geochemistry of Proterozoic granitic plutons from NewMexico, US. Chemical Geology, 21(1-2): 131-149.

Corfu, F. and Davis, D.W., 1991. Comment on "Archean hydrothermal zircon in the Abitibi greenstone belt: constraints on the timing of gold mineralization" by J.C. Claoue-Long, R.W. King and R. Kerrich. Earth and Planetary Science Letters, 104: 545-552.

Finch, R.J. and Hanchar, J.M., 2003. Structure and chemistry of zircon and zircongroup minerals. In Zircon (eds Hanchar, J.M. and Hoskin P.W.O.). Reviews in Mineralogy and Geochemistry, 53, 1-25.

Finch, R.J., Hanchar, J.M., Hoskin, P.W.O. and Burns, P.C., 2001. Rare-earth elements in synthetic zircon: Part 2. A single- crystal X-ray study of xenotime substitution. American Mineralogist, 86(5-6): 681-689.

Flood P. G. and Aitchison J. C. (1993) Recent advances in understanding the geological development of the New England Province of the New England Orogen. In: New England Orogen NEO'93 Conference Proceedings (eds. Flood P. G. and Aitchison J. C.), University of New England, pp. 61-67.

Günther, D., Frischknecht, R., Heinrich, C.A. and Kahlert, H.J., 1997. Capabilities of an Argon Fluoride $193 \mathrm{~nm}$ excimer laser for laser ablation inductively coupled plasma mass spectrometry microanalysis of geological materials. Journal of Analytical Atomic Spectrometry, 12(9): 939-944. 
Günther, D., Audétat, A., Frischknecht, R. and Heinrich, C.A., 1998. Quantitative analysis of major, minor and trace elements in fluid inclusions using laser ablation inductively coupled plasma mass spectrometry. Journal of Analytical Atomic Spectrometry, 13(4): 263-270.

Guo, J.F., Oreilly, S.Y. and Griffin, W.L., 1996. Zircon inclusions in corundum megacrysts. 1. Trace element geochemistry and clues to the origin of corundum megacrysts in alkali basalts. Geochimica et Cosmochimica Acta, 60(13): 23472363.

Halter, W.E., Pettke, T., Heinrich, C.A. and Rothen-Rutishauser, B., 2002. Major to trace element analysis of melt inclusions by laser- ablation ICP-MS: methods of quantification. Chemical Geology, 183(1-4): 63-86.

Hanchar, J.M. et al., 2001. Rare earth elements in synthetic zircon: Part 1. Synthesis, and rare earth element and phosphorus doping. American Mineralogist, 86(5-6): 667-680.

Heinrich, C.A., 1990. The chemistry of hydrothermal tin(-tungsten) ore deposition. Economic Geology, 85(3): 457-481.

Heinrich, C.A. et al., 2003. Quantitative multi-element analysis of minerals, fluid and melt inclusions by laser-ablation inductively-coupled-plasma massspectrometry. Geochimica et Cosmochimica Acta, 67(18): 3473-3497.

Henley H.F., Brown R.E., and Stroud W.J. (1999) The Mole Granite - extent of mineralization and exploration potential. In: Regional Geology, Tectonics and Metallogenesis of the New England Orogen (ed. Flood P. G.), University of New England, pp. 385-392.

Hinton, R.W. and Upton, B.G.J., 1991. The Chemistry of zircon - variations within and between large crystals from syenite and alkali basalt xenoliths. Geochimica et Cosmochimica Acta, 55(11): 3287-3302.

Hoskin, P.W.O., 1998. Minor and trace element analysis of natural zircon $\left(\mathrm{ZrSiO}_{4}\right)$ by SIMS and laser ablation ICPMS: A consideration and comparison of two broadly competitive techniques. Journal of Trace and Microprobe Techniques, 16(3): 301-326. 
Hoskin, P.W.O. and Ireland, T.R., 2000. Rare earth element chemistry of zircon and its use as a provenance indicator. Geology, 28(7): 627-630.

Hoskin, P.W.O. and Schaltegger, U., 2003. The composition of zircon and igneous and metamorphic petrogenesis. In Zircon (eds Hanchar, J.M. and Hoskin P.W.O.). Reviews in Mineralogy and Geochemistry, 53, 27-62.

Hoskin, P.W.O., Kinny, P.D. and Wyborn, D., 1998. Chemistry of hydrothermal zircon: Investigating timing and nature of water-rock interaction. In: G.B. Arehart and J.R. Hulston (editors), Proceedings of the $9^{\text {th }}$ international symposium of Water-Rock interaction. Balkema/Rotterdam/Brookfield, Taupo, New Zealand, pp. 545-548.

Hoskin, P.W.O., Kinny, P.D., Wyborn, D. and Chappell, B.W., 2000. Identifying accessory mineral saturation during differentiation in granitoid magmas: an integrated approach. Journal of Petrology, 41(9): 1365-1396.

Kerrich, R. and King, R., 1993. Hydrothermal zircon and baddeleyite in Val-d'Or Archean mesothermal gold deposits - characteristics, compositions, and fluidinclusion properties, with implications for timing of primary gold mineralization. Canadian Journal of Earth Sciences, 30(12): 2334-2351.

Kerrich, R. and Kyser, T.K., 1994. 100 Ma timing paradox of Archean gold, Abitibi Greenstone Belt (Canada) - new evidence from $\mathrm{U}-\mathrm{Pb}$ and $\mathrm{Pb}-\mathrm{Pb}$ evaporation ages of hydrothermal zircons. Geology, 22(12): 1131-1134.

Leach, A.M. and Hieftje, G.M., 2000. Methods for shot-to-shot normalization in laser ablation with an inductively coupled plasma time-of-flight mass spectrometer. Journal of Analytical Atomic Spectrometry, 15(9): 1121-1124.

Mahood, G. and Hildreth, W., 1983. Large partition-coefficients for trace-elements in high-silica rhyolites. Geochimica et Cosmochimica Acta, 47(1): 11-30.

McDonough, W.F. and Sun, S.S., 1995. The composition of the Earth. Chemical Geology, 120(3-4): 223-253.

Nesbitt, R.W. et al., 1999. U-Pb dating of stockwork zircons from the eastern Iberian Pyrite Belt. Journal of the Geological Society, 156: 7-10.

Pettke, T., Halter, W.E., Webster, J.D., Aigner-Torres, M. and Heinrich, C.A., 2004. Accurate quantification of melt inclusion chemistry by LA-ICPMS: A 
comparison with EMP and SIMS and advantages and possible limitations of these methods. Lithos 78(4), 333-361.

Poitrasson, F., Hanchar, J.M. and Schaltegger, U., 2002. The current state and future of accessory mineral research. Chemical Geology, 191(1-3): 3-24.

Reed, M.J., Candela, P.A. and Piccoli, P.M., 2000. The distribution of rare earth elements between monzogranitic melt and the aqueous volatile phase in experimental investigations at 800 degrees $\mathrm{C}$ and $200 \mathrm{MPa}$. Contributions to Mineralogy and Petrology, 140(2): 251-262.

Rosman, K.J.R. and Taylor, P.D.P., 1998. Isotopic compositions of the elements 1997. Pure and Applied Chemistry, 70(1): 217-235.

Rubatto, D., 2002. Zircon trace element geochemistry: partitioning with garnet and the link between U-Pb ages and metamorphism. Chemical Geology, 184(1-2): 123-138.

Rubin, J.N., Henry, C.D. and Price, J.G., 1993. The mobility of zirconium and other immobile elements during hydrothermal alteration. Chemical Geology, 110(1-3): 29-47.

Sawka, W.N., 1988. REE and the trace element variations in accessory minerals and hornblende from the strongly zoned Mc Murry Meadows Pluton, California. Transactions of the Royal Society of Edinburgh, 79: 157-168.

Schaltegger, U., Pettke, T., Audétat, A., Reusser, E. and Heinrich, C.A., 2005. Magmatic-to-hydrothermal crystallization of zircon and REE-phosphates in the Sn-W mineralized Mole Granite (NSW, Australia) over three million years - a geochemical and geochronological study. Chemical Geology, this volume.

Speer, J.A., 1982. The actinide orthosilicates. In: P.H. Ribbe (editor), Reviews in Mineralogy - Orthosilicates. Mineralogical Society of America, pp. 113-135.

Thomas, J.B., Bodnar, R.J., Shimizu, N. and Sinha, A.K., 2002. Determination of zircon/melt trace element partition coefficients from SIMS analysis of melt inclusions in zircon. Geochimica et Cosmochimica Acta, 66(16): 2887-2901.

Watson, E.B., 1979. Zircon saturation in felsic liquids - experimental results and applications to trace-element geochemistry. Contributions to Mineralogy and Petrology, 70(4): 407-419. 
Watson, E.B., Cherniak, D.J., Hanchar, J.M., Harrison, T.M. and Wark, D.A., 1997. The incorporation of Pb into zircon. Chemical Geology, 141(1-2): 19-31.

Yeats, C.J., McNaughton, N.J. and Groves, D.I., 1996. SHRIMP U-Pb geochronological constraints on Archean volcanic- hosted massive sulfide and lode gold mineralization at Mount Gibson, Yilgarn craton, Western Australia. Economic Geology, 91(8): 1354-1371. 


\section{Figure Captions}

Fig. 1. Photomicrographs showing typical occurrences of hydrothermal zircon as inclusions in free-grown quartz. (a) Cluster of 3 zircon grains (sample Yank 7.1), (b) cluster of 5 zircon grains and a feldspar inclusion marked by the arrow (Yank 20), (c) zircon inclusion on primary growth zone of a hydrothermal quartz crystal (sample Yank 7.1) that is cut by a trail of pseudosecondary fluid inclusions, and (d) cluster of 3 zircon and one brown thorite crystal (Yank 20). Note the multifaceted short-prismatic habit of most of the zircon crystals and the radial cracks in the host quartz crystal.

Fig. 2. Cathodoluminescence (a, b, d, e, f) and backscattered electron (c) images of zircon crystals. (a) Early magmatic zircon crystal showing a low-luminescent non-zoned core (growth Stage A), zoned overgrowth typical for magmatic zircon (growth Stage B), including a high-luminescent section and a final crystal-faceparallel, low-luminescent rim (sample vnlt). (b) Late-magmatic crystal cut perpendicular to its $\mathrm{C}$-axis, showing conspicuous sector zoning and magmatic zonation (growth Stage B; sample Yank 8.1c). The conspicuous marginal zone (Stage B1) cutting the magmatic zonation is visualized well in BSE mode (Fig. C). This feature, observed in a few grains, and suggests some hydrothermal alteration of the zircon inclusions. (d,e) Hydrothermal crystals showing an irregular pattern of strongly contrasting luminescence with no relationship to the crystal surfaces (growth Stage D; samples Yank 20c23 and Yank 20c42). (g) Zircon crystal from the biotite alteration selvage around the Paradise Lode, showing oscillatory growth in the core and an irregular, low-luminescent rim (sample Gadet 6.2).

Fig. 3. Transient LA-ICPMS signals of mineral inclusions in quartz crystals: (a) Hydrothermal zircon (sample Yank 20c34). Note the subtle zonation of the grain with respect to the $\mathrm{U} / \mathrm{Hf}$ ratio. (b) Late-magmatic thorite (sample 8.1E). Note the inclusion of a zircon crystal peaking around $60-70$ s as monitored by the concomitant increase in $\mathrm{Zr}$ and $\mathrm{Hf}$ signals. (c) Late-magmatic monazite.

Fig.4. Chondrite-normalized REE patterns for various generations of zircon, thorite and monazite. Data are shown for bulk inclusions (solid black line), core sections (solid gray line) and rim sections (dashed black line). (a) Early 
magmatic zircon, (b) late-magmatic zircon, (c) hydrothermal zircon, (d) latemagmatic and hydrothermal thorite and (e) late magmatic monazite, respectively. Note that the variation in REE patterns between late magmatic and hydrothermal thorite (Table 3) does not exceed that observed for hydrothermal thorite alone.

Fig. 5. (a) Plot $\mathrm{HfO}_{2} / \mathrm{Y}_{2} \mathrm{O}_{3}$ vs. $\mathrm{ZrO}_{2} / \mathrm{Y}_{2} \mathrm{O}_{3}$ showing a clear positive correlation as expected for the case where incorporation of $\mathrm{Zr}, \mathrm{Hf}$ and $\mathrm{Y}$ in zircon is dominated by xenotime-type coupled substitution. (b) The plot of Ta/Nb vs. $\mathrm{ZrO}_{2} / \mathrm{Y}_{2} \mathrm{O}_{3}$ shows two different trends from early to late crystallization of zircon, highlighted by gray arrows. The Paradise lode hydrothermal zircon crystals associated with biotite alteration show uniform $\mathrm{Ta} / \mathrm{Nb}$ ratios with variable $\mathrm{ZrO}_{2} / \mathrm{Y}_{2} \mathrm{O}_{3}$ while the Yankee Lodes zircon crystals reveal a clear positive correlation, suggesting that the $\mathrm{Nb} / \mathrm{Ta}$ ratio may be significantly fractionated between a silicic melt and a coexisting hydrothermal fluid.

Fig. 6. Chondrite-normalized REE patterns of core and rim analyses of zircon associated with biotite alteration from the Paradise Lode. Rim analyses are conspicuously enriched in REE, opposite to the trends documented for hydrothermal zircon from Yankee Lodes.

Fig. 7. Comparison of trends in chondrite-normalized REE patterns for zircon evolving from magmatic to hydrothermal crystallization (a, Yankee Lodes), core to rim trends for zircon associated with biotite alteration (b, Paradise Lode) and literature data for magmatic and hydrothermal zircon from the Boggy Plain Pluton (c, Hoskin et al., 1998). Trends from early to late crystallization of zircon, marked by gray arrows, are opposite for genetically similar zircon populations, suggesting that REE abundances and patterns alone are not indicative of the geological environment in which zircon crystallized. 
Figure 1

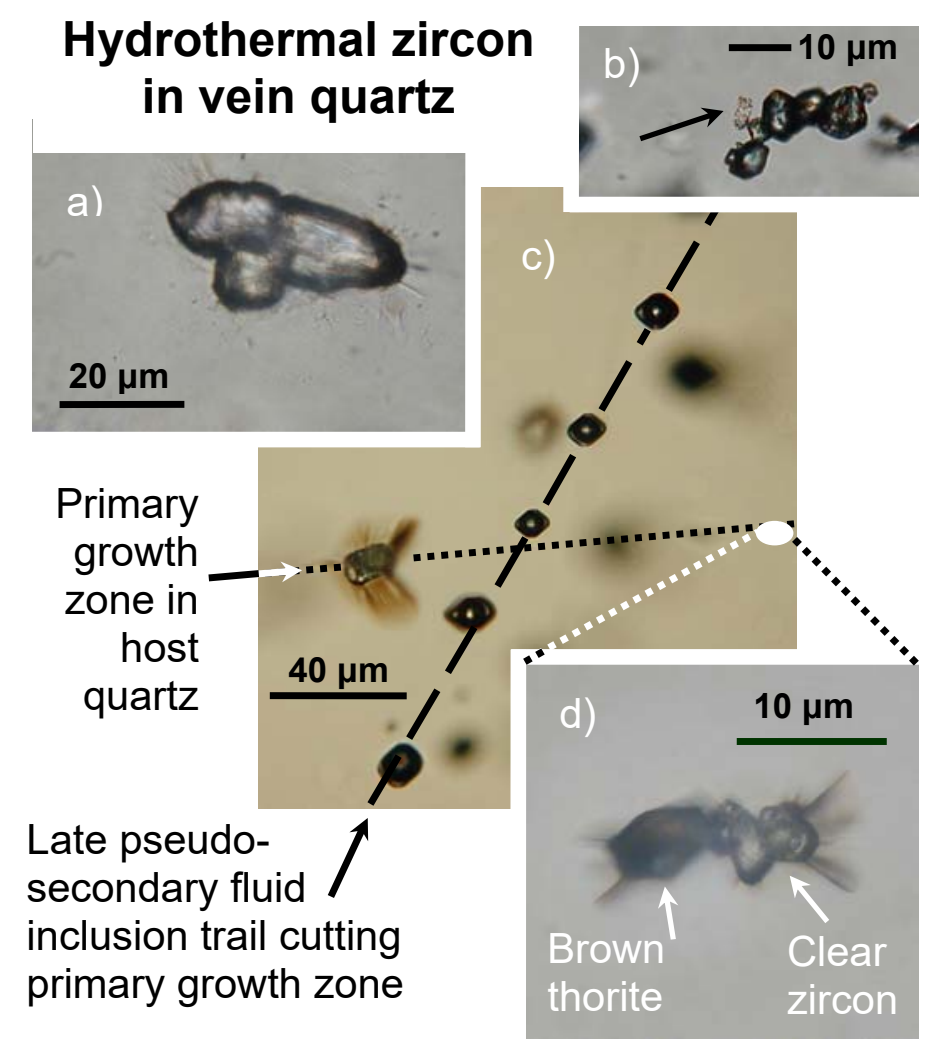



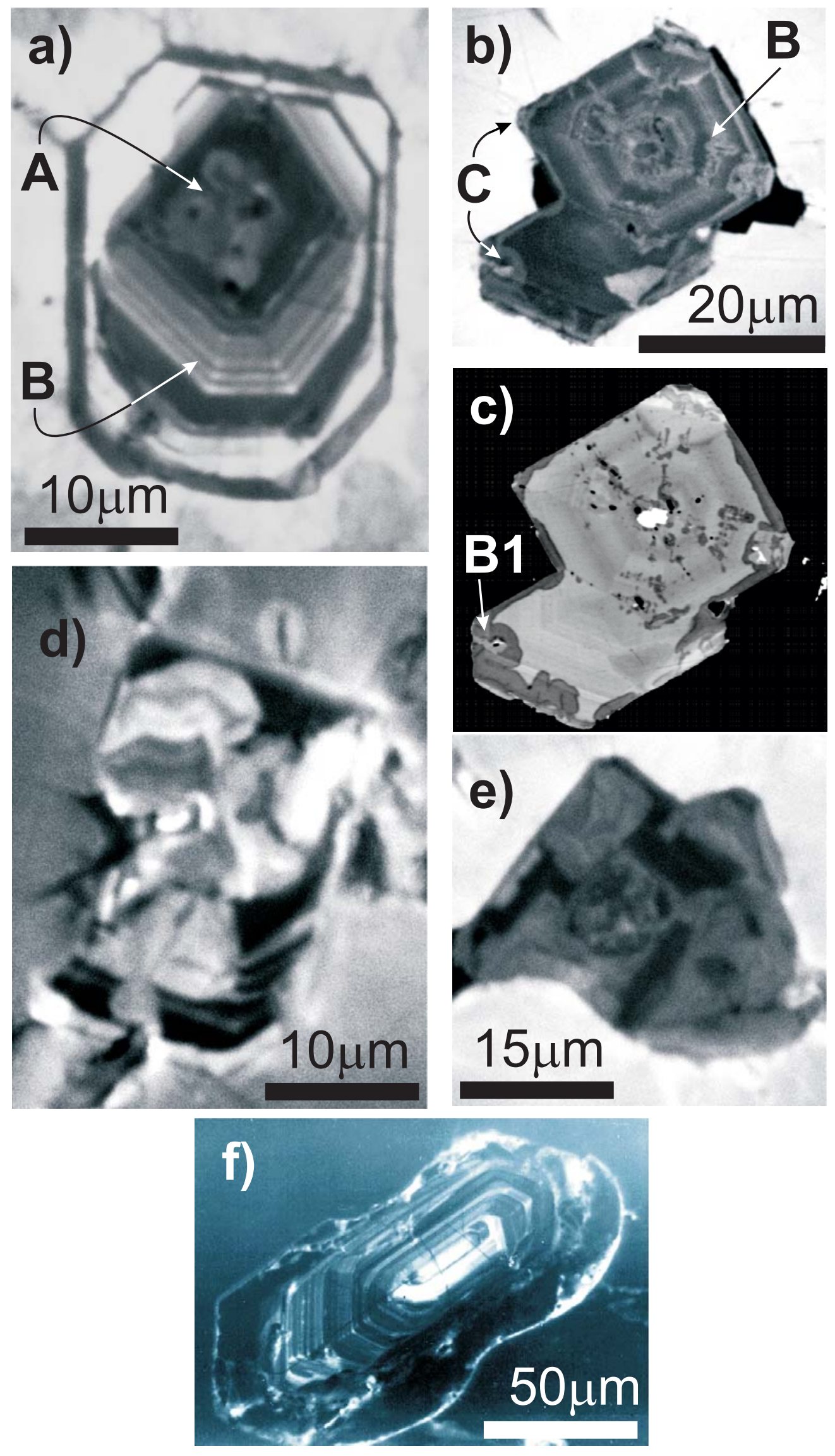

Figure 2 

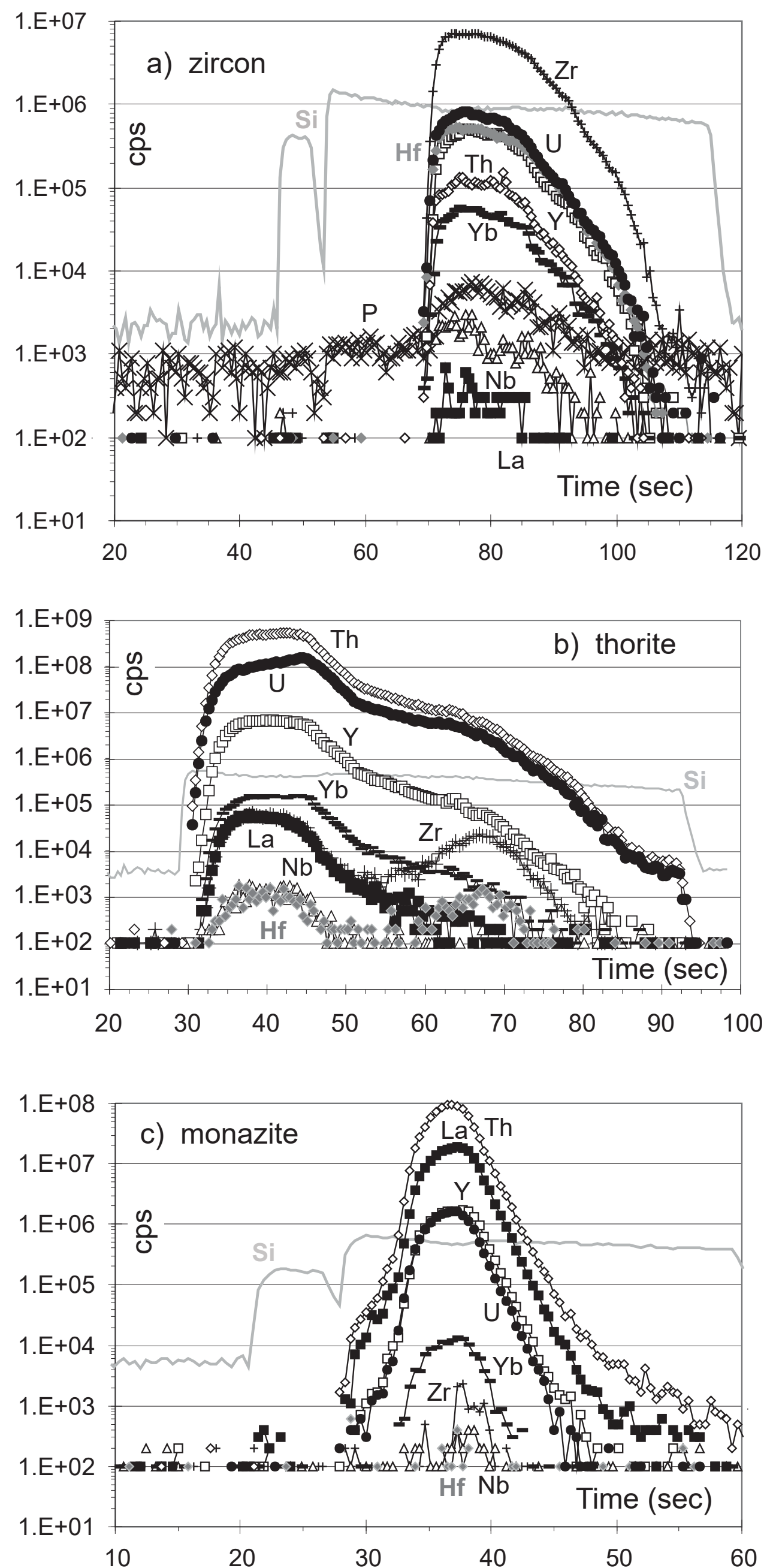

Figure 3 


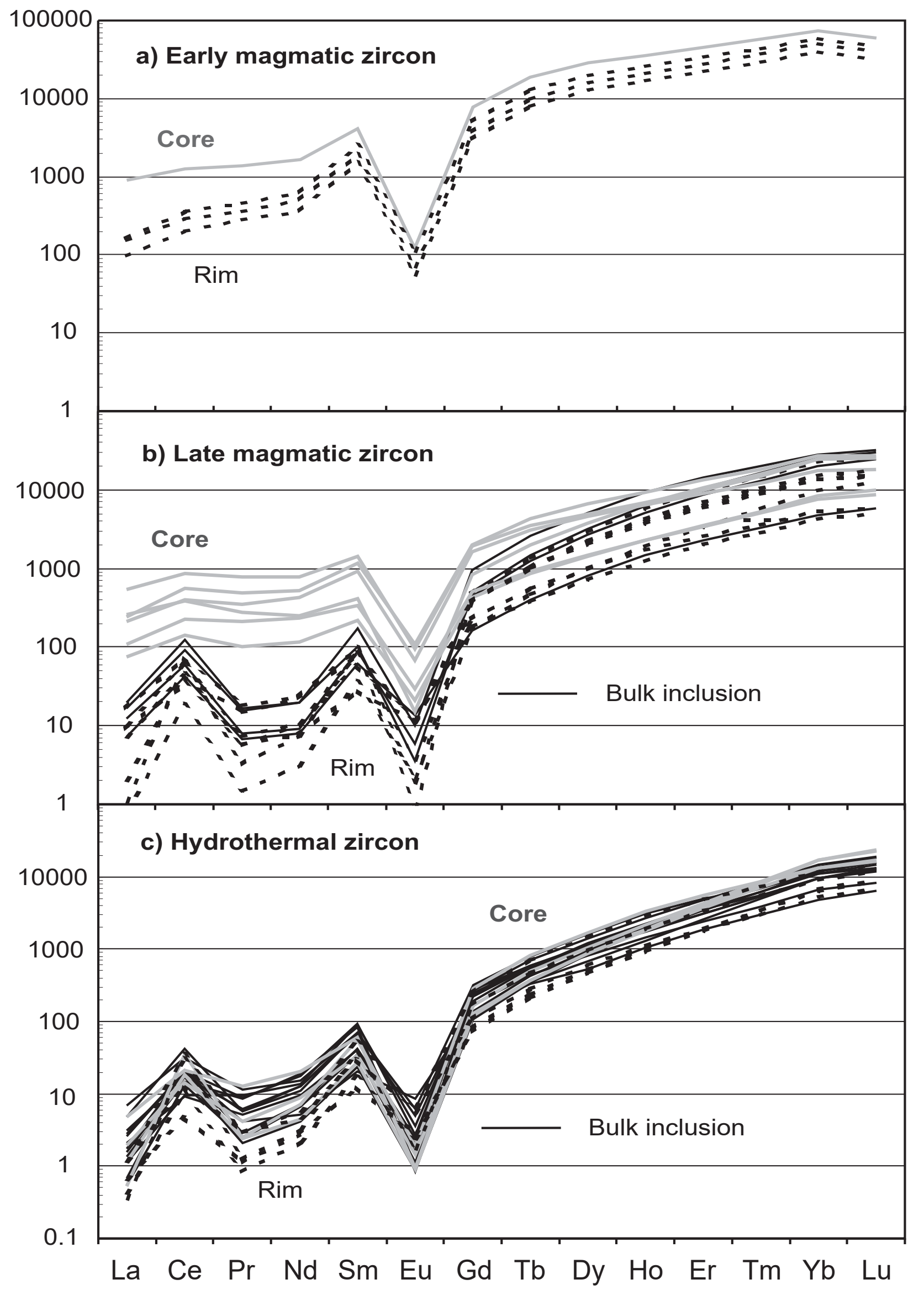

Figure 4abc 


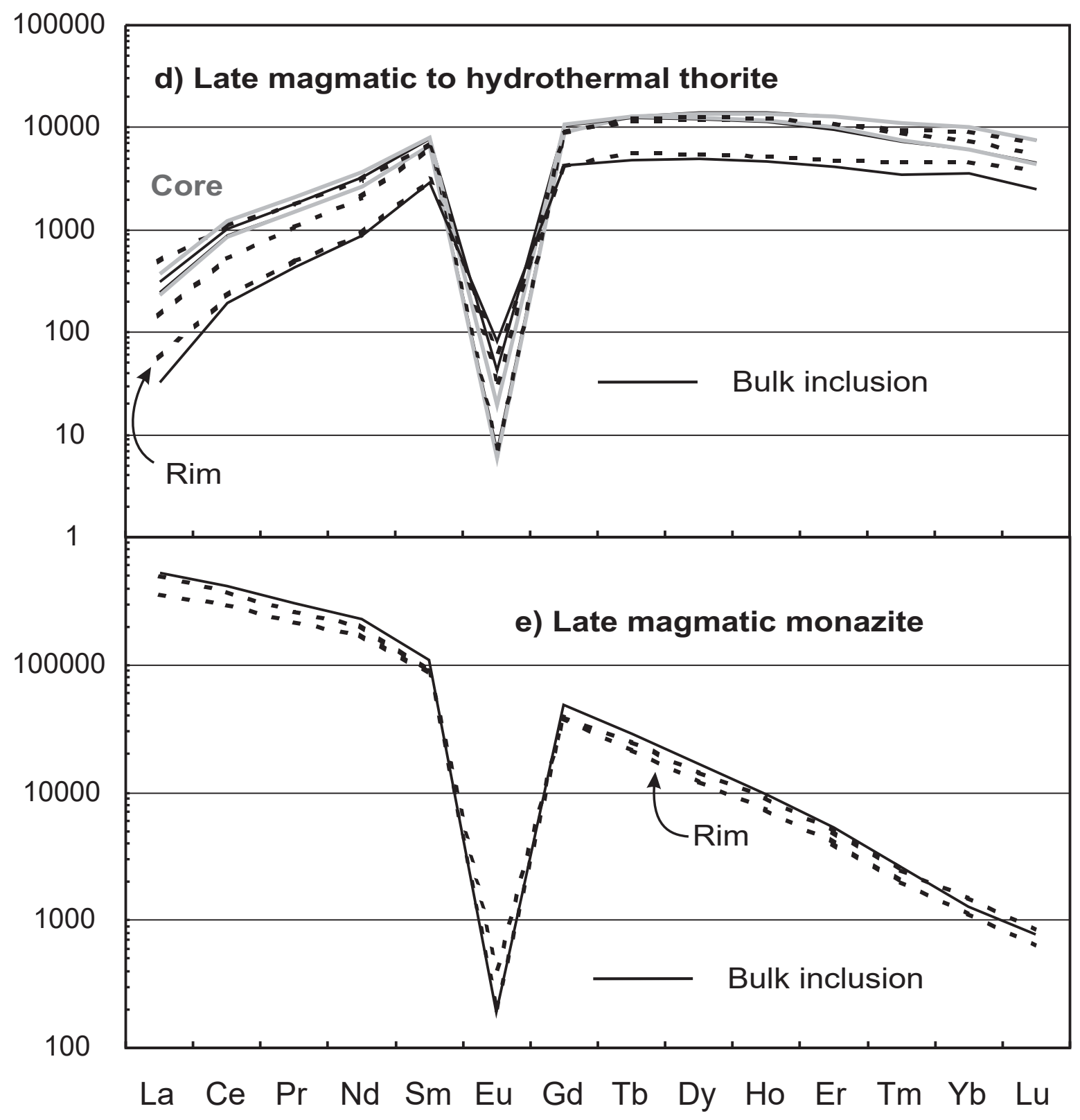

Figure 4de 


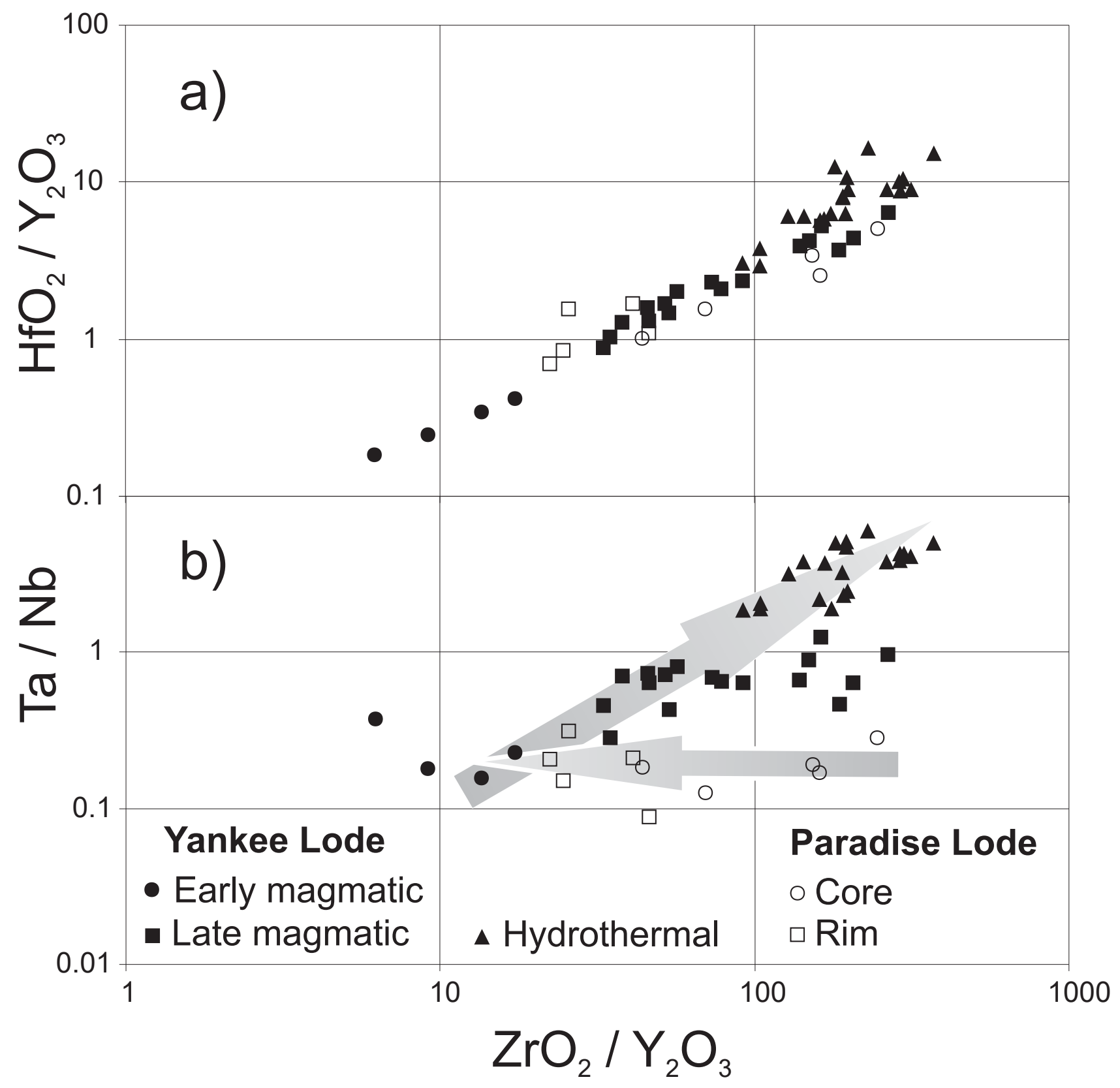

Figure 5 


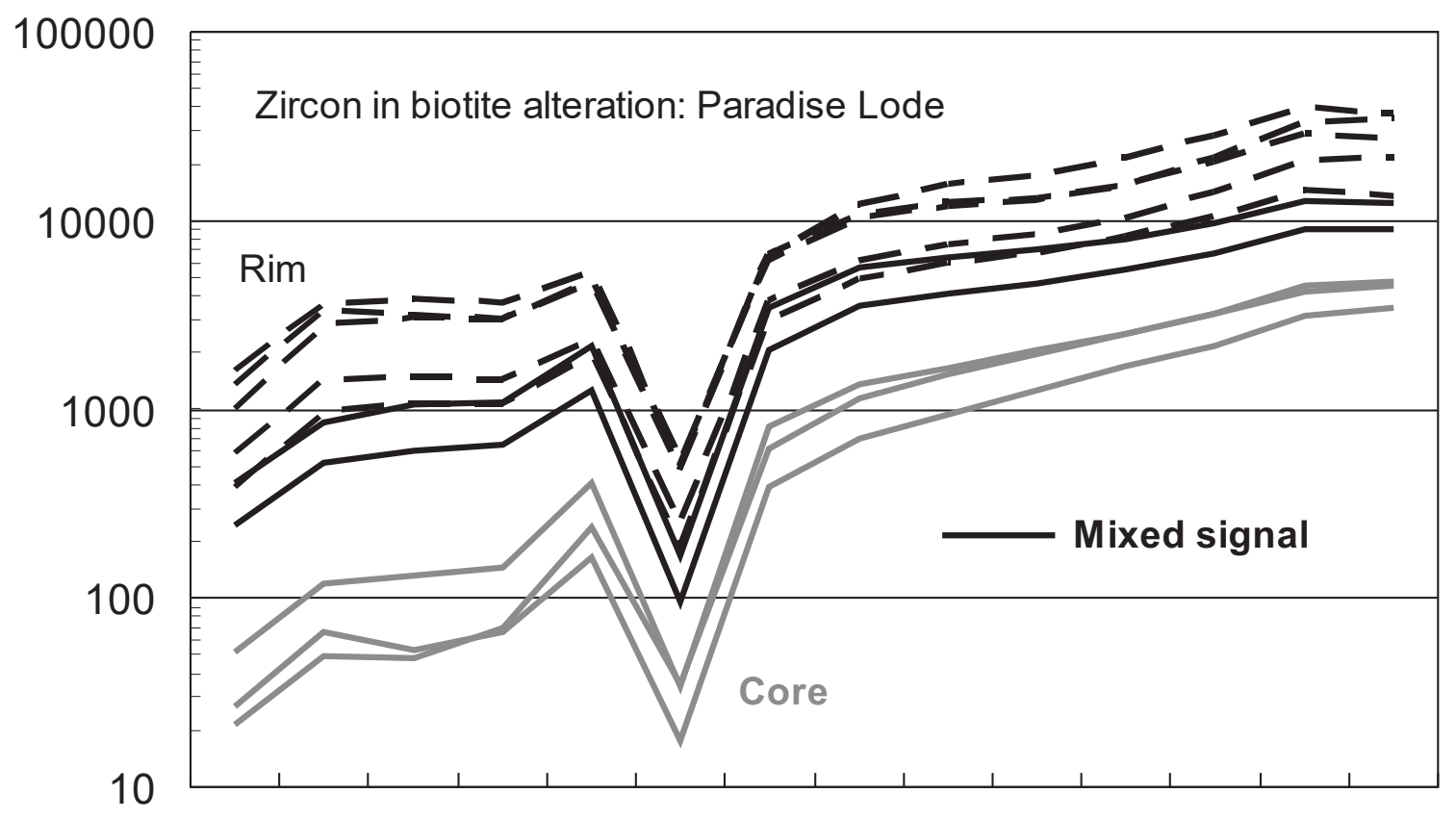

La Ce Pr Nd Sm Eu Gd Tb Dy Ho Er Tm Yb Lu

Figure 6 


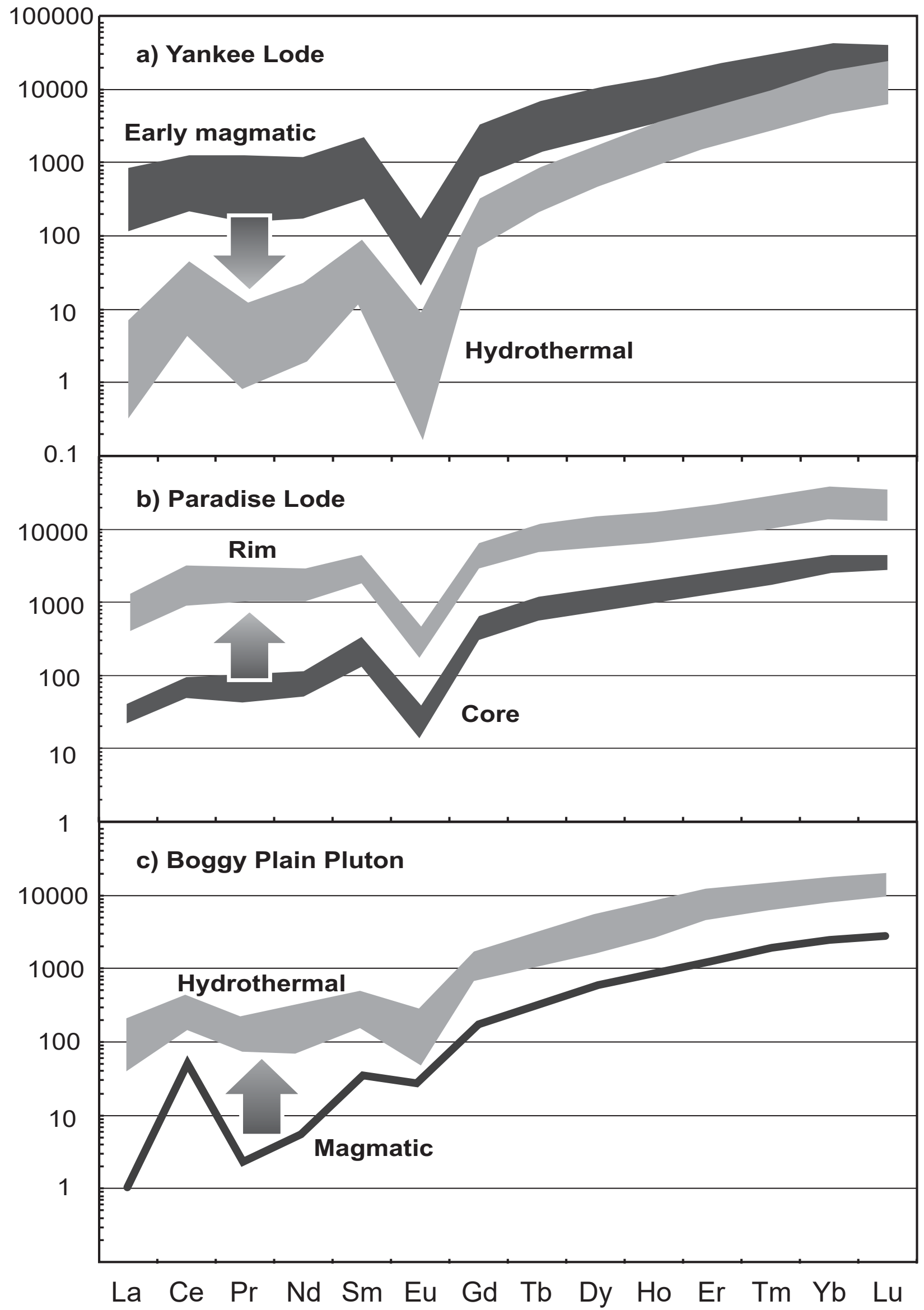

Figure 7 
Table 1: LA-ICP-MS machine and data acquisition parameters

\section{Excimer 193 nm ArF laser Compex 110I}

\begin{tabular}{|l|l|}
\hline - Output energy & $100-140 \mathrm{~mJ}$ \\
\hline - Energy density on sample & of the order of $10 \mathrm{~J} / \mathrm{cm}^{2}$ \\
\hline - Pulse duration & $15 \mathrm{~ns}$ \\
\hline - Repetition rate & $10 \mathrm{~Hz}$ \\
\hline - Pit sizes & \begin{tabular}{l} 
Between 8 and $80 \mu \mathrm{m}$ \\
\hline - Ablation cell
\end{tabular} \\
\hline - Cell He gas flow & $\begin{array}{l}\text { Plexiglass with anti-reflection } \\
\text { coated silica glass window }\end{array}$ \\
\hline
\end{tabular}

ELAN 6100 quadrupole ICP-MS

\begin{tabular}{|l|l|}
\hline - Nebulizer gas flow & $0.80-0.901 \mathrm{~min}^{-1} \mathrm{Ar}$ \\
\hline - Auxiliary gas flow & $0.75-0.901 \mathrm{~min}^{-1} \mathrm{Ar}$ \\
\hline - Cool gas flow & $13.0-15.01 \mathrm{~min}^{-1} \mathrm{Ar}$ \\
\hline - rf power & $1200-1300 \mathrm{kV}$ \\
\hline - Detector mode & $\begin{array}{l}\text { Dual, } 9 \text { orders of magnitude } \\
\text { linear dynamic range }\end{array}$ \\
\hline - Quadrupole settling time & $3 \mathrm{~ms}$ \\
\hline - Detector housing vacuum & $\begin{array}{l}1.5-2.8 * 10^{-5} \text { Torr } \\
\text { during analysis }\end{array}$ \\
\hline
\end{tabular}

Data acquisition parameters

\begin{tabular}{|c|c|}
\hline - Sweeps per reading & 1 \\
\hline - Readings per replicate & 300 \\
\hline - Replicates & 1 \\
\hline - Dwell time per isotope & $10 \mathrm{~ms}$ \\
\hline - Points per peak & 1 per measurement \\
\hline - Oxide production rate & Tuned to $<0.2 \%$ ThO \\
\hline - Isotopes analyzed & $\begin{array}{l}{ }^{7} \mathrm{Li},{ }^{23} \mathrm{Na},{ }^{27} \mathrm{Al},{ }^{29} \mathrm{Si},{ }^{31} \mathrm{P},{ }^{39} \mathrm{~K}, \\
{ }^{42} \mathrm{Ca},{ }^{45} \mathrm{Sc},{ }^{49} \mathrm{Ti},{ }^{55} \mathrm{Mn},{ }^{57} \mathrm{Fe}, \\
{ }^{89} \mathrm{Y},{ }^{91} \mathrm{Zr},{ }^{93} \mathrm{Nb},{ }^{118} \mathrm{Sn},{ }^{133} \mathrm{Cs}, \\
{ }^{139} \mathrm{La},{ }^{140} \mathrm{Ce},{ }^{141} \mathrm{Pr},{ }^{146}{ }^{\mathrm{Nd}}, \\
{ }^{147} \mathrm{Sm},{ }^{153} \mathrm{Eu},{ }^{157} \mathrm{Gd},{ }^{159} \mathrm{~Tb}, \\
{ }^{163} \mathrm{Dy},{ }^{165} \mathrm{Ho},{ }^{167} \mathrm{Er},{ }^{169} \mathrm{Tm}, \\
{ }^{173} \mathrm{Yb},{ }^{175} \mathrm{Lu},{ }^{178} \mathrm{Hf},{ }^{202} \mathrm{Hg}, \\
{ }^{204} \mathrm{~Pb},{ }^{206} \mathrm{~Pb},{ }^{207} \mathrm{~Pb},{ }^{208} \mathrm{~Pb}, \\
{ }^{209} \mathrm{Bi},{ }^{232} \mathrm{Th},{ }^{238} \mathrm{U}\end{array}$ \\
\hline
\end{tabular}


Table 2: Trace element data for hydrothermal quartz hosting zircon and thorite from the Mole Granite in Eastern Australia

\begin{tabular}{|c|c|c|c|c|c|c|c|}
\hline & & $\begin{array}{r}\mathrm{Li} \\
\mu \mathrm{g} / \mathrm{g}\end{array}$ & $\begin{array}{r}\text { Al } \\
\mu \mathrm{g} / \mathrm{g}\end{array}$ & $\begin{array}{r}\mathrm{SiO}_{2}{ }^{\#} \\
\mathrm{wt} \%\end{array}$ & $\begin{array}{r}\mathrm{P}_{2} \mathrm{O}_{5} \\
\mu \mathrm{g} / \mathrm{g}\end{array}$ & $\begin{array}{r}S n \\
\mu g / g\end{array}$ & $\begin{array}{r}B i \\
\mu g / g\end{array}$ \\
\hline ap27c13 & Yank 8.1E & 20.1 & 230 & 99.9 & na & 33.8 & $<0.030$ \\
\hline ap27c17 & Yank 8.1E & 29.4 & 210 & 99.9 & na & 34.5 & $<0.034$ \\
\hline ap27c18 & Yank 8.1E & 26.5 & 208 & 99.9 & na & 29.3 & $<0.029$ \\
\hline ap27c04 & Yank 7.1 & $<11.5$ & 181 & 99.9 & na & 26.5 & 0.047 \\
\hline ap27d03 & Yank 7.1 & 14.2 & 100 & 99.9 & na & 28.5 & 0.038 \\
\hline m_02a03 & Yank 7.1 & 22.1 & 192 & 99.9 & 17.5 & 23.7 & $<0.017$ \\
\hline m_02a06 & Yank 7.1 & 17.8 & 144 & 99.9 & 21.8 & 38.5 & $<0.019$ \\
\hline m_02a07 & Yank 7.1 & 14.2 & 137 & 99.9 & 26.2 & 35.9 & $<0.048$ \\
\hline m_02a09 & Yank 7.1 & 23.9 & 212 & 99.9 & 21.8 & 37.3 & 0.018 \\
\hline m_03a15 & Yank 7.1 & 11.2 & 89 & 99.9 & 26.2 & 42.6 & $<0.029$ \\
\hline m_03a16 & Yank 7.1 & 10.9 & 82 & 99.9 & 13.1 & 28.2 & 0.022 \\
\hline ap27a11 & Yank $20 \mathrm{~A} / 0$ & 14.2 & 178 & 99.9 & na & 8.8 & 0.025 \\
\hline ap27a13 & Yank 20 A/26 & 11.7 & 112 & 99.9 & na & 10.0 & 0.028 \\
\hline ap27a14 & Yank 20 A/26 & 10.1 & 109 & 99.9 & na & 8.8 & 0.022 \\
\hline ap27a03 & Yank 20B1 & 13.7 & 157 & 99.9 & na & 8.0 & 0.064 \\
\hline ap27a07 & Yank 20B1 & 17.7 & 176 & 99.9 & na & 7.9 & 0.063 \\
\hline ap27a08 & Yank 20B1 & 17.1 & 177 & 99.9 & na & 7.4 & 0.062 \\
\hline m_03a05 & Yank 20B2 & 14.5 & 151 & 99.9 & 17.5 & 31.8 & $<0.030$ \\
\hline m_03a08 & Yank 20B2 & 20.4 & 192 & 99.9 & 13.1 & 25.0 & 0.029 \\
\hline m_03a11 & Yank 20B2 & 17.4 & 178 & 99.9 & 13.1 & 20.8 & 0.019 \\
\hline m_03a13 & Yank 20B2 & $<12.4$ & 89 & 99.9 & $<34.9$ & 41.5 & $<0.041$ \\
\hline m_02a11 & Yank20E34 & 18.1 & 185 & 99.9 & 21.8 & 37.0 & $<0.016$ \\
\hline m_02a16 & Yank20E42 & 17.0 & 151 & 99.9 & 26.2 & 35.4 & $<0.064$ \\
\hline m_02a17 & Yank20E42 & 28.3 & 151 & 99.9 & 26.2 & 30.6 & $<0.064$ \\
\hline m_02a18 & Yank20E42 & 19.7 & 192 & 99.9 & 13.1 & 29.5 & 0.022 \\
\hline average & & 17 & 150 & 99.9 & 20 & 26 & 0.04 \\
\hline
\end{tabular}

$<$ value Concentrations are below the LOD given ( $3 *$ stdev of background divided by sensitivity) na not analyzed

\# Internal standard element used for quantification 
Table 3: Major to trace element data for magmatic and hydrothermal zircon and thorite from the Mole Granite in Eastern Australi:

\begin{tabular}{|c|c|c|c|c|c|c|c|c|c|c|c|c|c|c|c|c|c|c|c|}
\hline Zircon & & & $\begin{array}{r}\mathrm{Li} \\
\mu \mathrm{g} / \mathrm{g}\end{array}$ & $\begin{array}{r}\mathrm{Na} 2 \mathrm{O} \\
\mathrm{wt} \%\end{array}$ & $\begin{array}{r}\mathrm{Al} 2 \mathrm{O} 3 \\
\mathrm{wt} \%\end{array}$ & $\begin{array}{r}\mathbf{P} 205 \\
\mathbf{w t} \%\end{array}$ & $\begin{array}{l}\text { K2O } \\
\text { wt \% }\end{array}$ & $\begin{array}{l}\mathrm{CaO} \\
\mathrm{wt} \%\end{array}$ & $\begin{array}{r}\mathrm{Sc} \\
\mu \mathrm{g} / \mathrm{g}\end{array}$ & $\begin{array}{l}\mathrm{TiO2} \\
\mathrm{wt} \%\end{array}$ & $\begin{array}{l}\text { MnO } \\
\text { wt } \%\end{array}$ & $\begin{array}{l}\mathrm{FeO} \\
\mathrm{wt} \%\end{array}$ & $\begin{array}{r}\text { Y2O3 } \\
\text { wt } \%\end{array}$ & $\begin{array}{c}\mathrm{ZrO2} \\
\mathrm{wt} \%\end{array}$ & $\begin{array}{r}\mathrm{Nb} \\
\mu \mathrm{g} / \mathrm{g}\end{array}$ & $\begin{array}{r}\mathrm{Sn} \\
\mu \mathrm{g} / \mathrm{g}\end{array}$ & $\begin{array}{r}\text { Cs } \\
\mu \mathrm{g} / \mathrm{g}\end{array}$ & $\begin{array}{r}\text { La } \\
\mu \mathrm{g} / \mathrm{g}\end{array}$ & $\begin{array}{r}\mathrm{Ce} \\
\mu \mathrm{g} / \mathrm{g}\end{array}$ \\
\hline \multicolumn{20}{|c|}{ VNLT 107: Early magmatic zircon } \\
\hline ap27e05 & incl & core interval & 16 & $<0.001$ & 1.12 & na & $<0.001$ & na & na & na & $<0.001$ & 8.327 & 7.55 & 46.8 & 126 & 29 & 112 & 225 & 805 \\
\hline ap27e05 & incl & rim interval & 11 & $<0.001$ & 1.39 & na & $<0.001$ & na & na & na & $<0.001$ & 3.698 & 5.87 & 53.8 & 129 & 107 & 59 & 41 & 228 \\
\hline ap27e03 & $\exp$ & rim interval & $<13$ & 0.015 & 0.68 & na & 0.028 & na & na & na & 0.053 & 1.787 & 4.26 & 57.5 & 89 & 24 & 8.2 & 38 & 184 \\
\hline ap27e04 & $\exp$ & rim interval & $<26$ & 0.007 & 0.45 & na & 0.018 & na & na & na & 0.042 & 0.746 & 3.47 & 59.9 & 55 & 32 & 2.0 & 24 & 129 \\
\hline \multicolumn{20}{|c|}{ Yankee 8.1 E: Late magmatic zircon } \\
\hline ap27a16 & incl & bulk crystal & 494 & 0.002 & $<0.01$ & na & $<0.001$ & na & na & na & 0.002 & $<0.001$ & 1.12 & 63.2 & 45 & 183 & 0.3 & 3.07 & 39 \\
\hline ap27a17 & incl & bulk crystal & 575 & 0.003 & 0.44 & na & 0.011 & na & na & na & $<0.001$ & 0.056 & 0.32 & 65.8 & 7.2 & 131 & 1.0 & 1.80 & 27 \\
\hline ap27c17 & incl & bulk crystal & 1383 & 0.039 & 1.92 & na & 0.018 & na & na & na & 0.002 & $<0.001$ & 1.87 & 61.6 & 68 & 4075 & 2.1 & 4.85 & 80 \\
\hline ap27c18 & incl & bulk crystal & 663 & 0.088 & 3.85 & na & 0.182 & na & na & na & 0.003 & 0.014 & 1.35 & 61.6 & 81 & 819 & 77 & 4.12 & 59 \\
\hline ap27b05 & exp & core interval & 75 & 0.189 & 0.30 & na & 0.011 & na & na & na & 0.116 & 0.490 & 1.35 & 62.2 & 129 & 19 & 24 & 65 & 246 \\
\hline ap27b06 & exp & core interval & 23 & 0.268 & 0.59 & na & 0.033 & na & na & na & 0.150 & 3.201 & 1.55 & 59.0 & 337 & 104 & 106 & 135 & 558 \\
\hline ap27c08 & exp & core interval & 2.8 & 0.028 & 0.08 & na & 0.012 & na & na & na & 0.007 & 0.287 & 1.19 & 63.6 & 89 & 65 & 6.0 & 53 & 258 \\
\hline ap27c14 & exp & core interval & 2.9 & 0.018 & $<0.01$ & na & 0.022 & na & na & na & 0.005 & 0.193 & 0.47 & 65.2 & 31 & 49 & 5.0 & 27 & 147 \\
\hline ap27c15 & exp & core interval & $<3.1$ & 0.010 & 0.01 & na & 0.006 & na & na & na & 0.004 & 0.268 & 0.44 & 65.0 & 47 & 24 & 1.8 & 19 & 91 \\
\hline ap27c16 & exp & core interval & 2.0 & 0.117 & 0.26 & na & 0.026 & na & na & na & 0.149 & 0.527 & 1.75 & 60.9 & 197 & 39 & 5.0 & 61 & 358 \\
\hline ap27a17 & incl & rim interval & 355 & $<0.002$ & 0.27 & na & $<0.003$ & na & na & na & $<0.004$ & $<0.005$ & 0.25 & 65.9 & 2.8 & 76 & 1.1 & 2.3 & 22 \\
\hline ap27b04 & incl & rim interval & 16 & 0.017 & $<0.01$ & na & 0.011 & na & na & na & 0.001 & 0.006 & 1.22 & 63.2 & 63 & $<3.6$ & 2.1 & 0.27 & 43 \\
\hline ap27c06 & $\exp$ & rim interval & 26 & 0.032 & $<0.01$ & na & 0.005 & na & na & na & 0.010 & 0.047 & 0.40 & 65.1 & 36 & 78 & 5.4 & $<0.2$ & 12 \\
\hline ap27c07 & $\exp$ & rim interval & $<11$ & 0.002 & $<0.01$ & na & 0.002 & na & na & na & 0.001 & $<0.001$ & 0.36 & 66.3 & 7.0 & 37 & 0.2 & 1.8 & 27 \\
\hline ap27c10 & $\exp$ & rim interval & 307 & 0.006 & $<0.01$ & na & 0.009 & na & na & na & $<0.001$ & 0.380 & 0.82 & 64.3 & 18 & 257 & 0.5 & 2.5 & 39 \\
\hline ap27c11 & $\exp$ & rim interval & $<21$ & 0.008 & 0.01 & na & 0.005 & na & na & na & 0.001 & $<0.001$ & 0.71 & 64.9 & 29 & 9.4 & 0.4 & 4.2 & 46 \\
\hline ap27c13 & $\exp$ & rim interval & 383 & 0.002 & $<0.01$ & na & $<0.001$ & na & na & na & $<0.001$ & $<0.001$ & 0.87 & 64.1 & 32 & 513 & $<0.5$ & 0.50 & 30 \\
\hline \multicolumn{20}{|c|}{ Hydrothermal zircon (Yankee Lodes) } \\
\hline ap27a03 & Yank 20B1, incl & bulk crystal & 455 & $<0.002$ & 0.13 & na & $<0.002$ & na & na & na & na & $<0.003$ & 0.44 & 63.4 & 28 & 302 & 0.1 & 0.17 & 13 \\
\hline ap27a15 & Yank20 $\mathrm{C} / 34$, incl & bulk crystal & 108 & 0.050 & $<0.10$ & na & $<0.001$ & na & na & na & na & $<0.006$ & 0.32 & 63.4 & 43 & $<1.3$ & 5.2 & 0.75 & 11 \\
\hline $\mathrm{m} \_02 \mathrm{a} 06$ & Yank 7.1, incl & bulk crystal & 109 & 0.003 & 0.13 & 0.22 & 0.003 & $<0.06$ & na & 0.003 & na & $<0.003$ & 0.32 & 62.5 & 33 & 271 & 2.0 & 0.13 & 8 \\
\hline m-02a07 & Yank 7.1, incl & bulk crystal & 97 & 0.019 & 0.11 & 0.21 & 0.002 & $<0.10$ & na & 0.002 & na & $<0.001$ & 0.36 & 63.4 & 37 & 183 & 1.8 & 0.67 & 12 \\
\hline m_02a12 & Yank 20C42, incl & bulk crystal & 86 & 0.028 & 0.14 & 0.25 & 0.028 & $<0.11$ & na & 0.003 & na & 0.055 & 0.39 & 63.5 & 18 & 262 & 3.7 & 1.61 & 19 \\
\hline m_02a16 & Yank 20C42, incl & bulk crystal & 189 & $<0.004$ & 0.26 & 0.17 & $<0.004$ & $<0.43$ & na & 0.004 & na & $<0.004$ & 0.22 & 64.0 & 12 & 365 & $<0.4$ & $<0.6$ & 12 \\
\hline m_03a03 & Yank 20B2, incl & bulk crystal & 117 & 0.001 & 0.09 & 0.21 & $<0.001$ & $<0.15$ & na & 0.010 & na & $<0.010$ & 0.33 & 63.9 & 21 & 197 & 0.2 & 0.27 & 5.8 \\
\hline m_03a05 & Yank 20B2, incl & bulk crystal & 104 & 0.016 & 0.16 & 0.28 & 0.002 & $<0.19$ & na & 0.016 & na & 0.016 & 0.61 & 63.6 & 16 & 188 & 1.4 & 1.15 & 26 \\
\hline m_03a07 & Yank 20B2, incl & bulk crystal & 51 & 0.010 & 0.04 & 0.15 & 0.003 & $<0.03$ & na & $<0.001$ & na & $<0.001$ & 0.24 & 64.3 & 12 & 54 & 0.2 & 0.37 & 10 \\
\hline m_03a08 & Yank 20B2, 2 grains, incl & bulk crystal & 97 & 0.013 & 0.16 & 0.29 & 0.013 & $<0.02$ & na & 0.013 & na & 0.038 & 0.49 & 62.6 & 36 & 176 & 1.2 & 0.41 & 12 \\
\hline m_03a11 & Yank 20B2, 2 grains, incl & bulk crystal & 119 & 0.001 & 0.19 & 0.19 & 0.014 & $<0.03$ & na & 0.014 & na & 0.029 & 0.33 & 63.3 & 30 & 151 & 0.7 & 0.32 & 8.9 \\
\hline m_03a15 & Yank 7.1, incl & bulk crystal & 75 & 0.419 & 0.93 & 0.15 & 0.081 & $<0.26$ & na & $<0.001$ & na & 0.110 & 0.21 & 62.8 & 20 & 159 & 15 & 0.49 & 5.6 \\
\hline ap27a11 & Yank 20A/0, incl & core interval & 26 & 0.047 & $<0.12$ & na & 0.006 & na & na & na & 0.004 & $<0.011$ & 0.27 & 61.9 & 47 & 80 & 4.8 & 0.48 & 9.1 \\
\hline ap27a12 & Yank 20A/0, incl & core interval & 214 & 0.162 & 0.23 & na & 0.014 & na & na & na & 0.012 & 0.016 & 0.34 & 61.8 & 58 & 49 & 12 & 1.18 & 13 \\
\hline ap27a14 & Yank20 A/26, incl & core interval & 32 & 0.006 & $<0.05$ & na & 0.005 & na & na & na & 0.002 & $<0.002$ & 0.69 & 63.6 & 25 & 100 & 1.9 & 0.13 & 22 \\
\hline ap27a15 & Yank20 C/34, exp & core interval & 16 & 0.058 & $<0.07$ & na & 0.009 & na & na & na & 0.003 & 0.020 & 0.33 & 63.5 & 40 & 5.3 & 3.5 & 0.28 & 11 \\
\hline ap27a05 & Yank 20B1, exp & rim interval & 16 & 0.001 & $<0.01$ & na & $<0.005$ & na & na & na & 0.001 & 0.015 & 0.17 & 64.1 & 22 & 3.5 & 0.7 & 0.16 & 2.9 \\
\hline ap27a06 & Yank 20B1, exp & rim interval & 14 & $<0.002$ & $<0.01$ & na & 0.003 & na & na & na & na & 0.033 & 0.21 & 64.9 & 10 & 4.7 & 1.0 & 0.29 & 7.8 \\
\hline ap27a08 & Yank 20B1, exp & rim interval & 549 & 0.007 & $<0.13$ & na & 0.002 & na & na & na & na & $<0.008$ & 0.22 & 64.3 & 23 & 201 & 0.1 & 0.11 & 6.6 \\
\hline ap27a14 & Yank20 A/26, incl & rim interval & 950 & 0.021 & $<0.14$ & na & 0.010 & na & na & na & 0.004 & 0.042 & 0.61 & 63.3 & 30 & 807 & 4.2 & 0.29 & 22 \\
\hline m_03a16 & Yank 7.1, incl & rim interval & 255 & 0.083 & 0.13 & 0.18 & 0.033 & 0.12 & na & $<0.002$ & na & 0.366 & 0.38 & 63.4 & 23 & 629 & 5.9 & $<0.08$ & 18 \\
\hline \multicolumn{20}{|c|}{ Gadet 6.2: Zircon associated with biotite alteration (Paradise Lode) } \\
\hline ap27f03 & in Bt, exp, 20 mu pit & rim & $<10$ & 0.035 & 1.1 & na & 0.032 & na & na & na & 0.189 & 0.816 & 1.45 & 59.4 & 113 & 63 & 9.1 & 139 & 872 \\
\hline ap27f04 & in $\mathrm{Bt}$, exp, $20 \mathrm{mu}$ pit & core & $<16$ & 0.002 & 0.07 & na & 0.003 & na & na & na & 0.006 & 0.096 & 0.42 & 64.0 & 16 & 13 & 0.53 & 12 & 74 \\
\hline ap27f05 & in Bt, exp, $20 \mathrm{mu}$ pit & rim & $<16$ & 0.024 & 0.65 & na & 0.014 & na & na & na & 0.129 & 0.548 & 1.33 & 61.5 & 76 & 60 & 4.2 & 93 & 592 \\
\hline ap27f06 & in Bt, exp, 20 mu pit & core & $<6.5$ & 0.000 & 0.02 & na & 0.002 & na & na & na & 0.001 & 0.020 & 0.40 & 64.7 & 6.0 & 5.4 & 0.13 & 5.1 & 30 \\
\hline ap27f07 & in Bt, exp, $20 \mathrm{mu}$ pit & rim & $<22$ & 0.035 & 1.6 & na & 0.098 & na & na & na & 0.251 & 2.378 & 2.50 & 55.7 & 345 & 125 & 77 & 322 & 2064 \\
\hline ap27f08 & in Bt, exp, 20 mu pit & core & $<18$ & 0.001 & 0.03 & na & 0.002 & na & na & na & 0.001 & 0.028 & 0.26 & 64.4 & 7.1 & 8.8 & 0.12 & 6.4 & 41 \\
\hline ap27f10 & in Bt, exp, 20 mu pit & rim & $<17$ & 0.069 & 1.8 & na & 0.049 & na & na & na & 0.327 & 1.350 & 2.17 & 55.7 & 271 & 122 & 20 & 240 & 1711 \\
\hline ap27f09 & in Bt, exp, 20 mu pit & core & $<24$ & 0.023 & 0.29 & na & 0.024 & na & na & na & 0.041 & 0.341 & 0.90 & 62.8 & 48 & 38 & 1.6 & 58 & 317 \\
\hline ap27f12 & in Bt, exp, 20 mu pit & rim & $<17$ & 0.072 & 2.0 & na & 0.067 & na & na & na & 0.340 & 1.569 & 2.25 & 55.6 & 339 & 134 & 61 & 385 & 2232 \\
\hline ap27f11 & in Bt, exp, 20 mu pit & core & $<12$ & 0.036 & 0.55 & na & 0.039 & na & na & na & 0.075 & 2.676 & 1.35 & 59.6 & 64 & 77 & 5.1 & 96 & 527 \\
\hline Thorite & & & $\begin{array}{r}\mathrm{Li} \\
\mathrm{ppm}\end{array}$ & $\begin{array}{r}\mathrm{Na} 2 \mathrm{O} \\
\mathrm{wt} \%\end{array}$ & $\begin{array}{r}\mathrm{Al} 2 \mathrm{O} 3 \\
\mathrm{wt} \%\end{array}$ & $\begin{array}{r}\mathbf{P} 205 \\
\mathbf{w t} \%\end{array}$ & $\begin{array}{l}\text { K2O } \\
\text { wt } \%\end{array}$ & $\begin{array}{l}\mathrm{CaO} \\
\mathrm{wt} \%\end{array}$ & $\begin{array}{r}\mathrm{Sc} \\
\mathrm{ppm}\end{array}$ & $\begin{array}{l}\mathrm{TiO2} \\
\mathrm{wt} \%\end{array}$ & $\begin{array}{r}\text { Mno } \\
\text { wt } \%\end{array}$ & $\begin{array}{l}\mathrm{FeO} \\
\mathrm{wt} \%\end{array}$ & $\begin{array}{r}\text { Y2O3 } \\
\text { wt } \%\end{array}$ & $\begin{array}{r}\mathrm{Zr} \\
\mathrm{ppm}\end{array}$ & $\begin{array}{r}\mathrm{Nb} \\
\mathrm{ppm}\end{array}$ & $\begin{array}{r}\text { Sn } \\
\text { ppm }\end{array}$ & $\begin{array}{r}\mathrm{Cs} \\
\mathrm{ppm}\end{array}$ & $\begin{array}{r}\text { La } \\
\text { ppm }\end{array}$ & $\begin{array}{r}\mathrm{Ce} \\
\mathrm{ppm}\end{array}$ \\
\hline \multicolumn{20}{|c|}{ Yankee 8.1 E: Late magmatic thorite } \\
\hline ap27b03 & incl & bulk crystal & 20 & 0.008 & 0.06 & na & 0.007 & na & 1.9 & na & 0.001 & 0.011 & 1.51 & 264 & 6.4 & 13 & 7.6 & 58 & 543 \\
\hline ap27b03 & incl & core interval & 22 & 0.004 & 0.02 & na & 0.004 & na & 0.6 & na & 0.001 & 0.012 & 1.52 & 259 & 5.9 & 5.3 & 3.0 & 55 & 530 \\
\hline ap27a18 & incl & rim interval & 18 & 0.003 & 0.07 & na & 0.015 & na & 1.1 & na & 0.001 & 0.013 & 1.79 & 294 & 8.2 & 5.8 & 12 & 115 & 681 \\
\hline Hydrothe & rmal thorite & & & & & & & & & & & & & & & & & & \\
\hline ap27c03 & incl & bulk & 30 & $<0.001$ & $<0.01$ & na & 0.026 & na & 4.5 & na & 0.026 & 0.026 & 1.67 & 313 & 4.5 & 81 & 0.1 & 73 & 627 \\
\hline ap27c03 & incl & core interval & 23 & $<0.001$ & $<0.01$ & na & $<0.001$ & na & 1.6 & na & 0.027 & 0.027 & 1.74 & 287 & 4.9 & 35 & $<0.1$ & 89 & 751 \\
\hline ap27c04 & incl & rim interval & 86 & 0.036 & 0.09 & na & $<0.001$ & na & 6.1 & na & $<0.001$ & $<0.001$ & 1.44 & 164 & 6.1 & 91 & 0.2 & 34 & 325 \\
\hline m_03a12 & incl & bulk crystal & 21 & 0.008 & 0.09 & 0.48 & $<0.008$ & $<0.42$ & na & 0.017 & na & $<0.025$ & 0.83 & 59 & 1.0 & 128 & $<0.2$ & 8 & 118 \\
\hline m_03a13 & incl & rim interval & 124 & 0.003 & 0.03 & 0.50 & $<0.002$ & $<0.21$ & na & 0.013 & na & $<0.007$ & 0.89 & 14572 & 1.3 & 53 & 0.3 & 13 & 137 \\
\hline
\end{tabular}

Yankee 8.1 E: Late magmatic monazite

\begin{tabular}{|c|c|c|c|c|c|c|c|c|c|c|c|c|c|c|c|c|c|c|c|}
\hline & & & $\begin{array}{r}\mathrm{Li} \\
\mathrm{ppm}\end{array}$ & $\begin{array}{r}\mathrm{Na2O} \\
\mathbf{w t} \%\end{array}$ & $\begin{array}{r}\mathrm{Al} 2 \mathrm{O} 3 \\
\mathrm{wt} \%\end{array}$ & $\begin{array}{r}\mathbf{P} 205 \\
\mathbf{w t} \%\end{array}$ & $\begin{array}{l}\text { K2O } \\
\text { wt\% }\end{array}$ & $\begin{array}{l}\mathrm{CaO} \\
\mathrm{wt} \%\end{array}$ & $\begin{array}{r}\text { Sc } \\
\text { ppm }\end{array}$ & $\begin{array}{l}\mathrm{TiO2} \\
\text { wt } \%\end{array}$ & $\begin{array}{l}\text { Mno } \\
\text { wt } \%\end{array}$ & $\begin{array}{l}\mathrm{FeO} \\
\mathbf{w t} \%\end{array}$ & $\begin{array}{r}\text { Y2O3 } \\
\text { wt } \%\end{array}$ & $\begin{array}{r}\mathrm{Zr} \\
\mathrm{ppm}\end{array}$ & $\begin{array}{r}\mathrm{Nb} \\
\mathrm{ppm}\end{array}$ & $\begin{array}{r}\text { Sn } \\
\text { ppm }\end{array}$ & $\begin{array}{r}\text { Cs } \\
\text { ppm }\end{array}$ & $\begin{array}{r}\text { La } \\
\text { ppm }\end{array}$ & $\begin{array}{r}\mathrm{Ce} \\
\mathrm{ppm}\end{array}$ \\
\hline ap27c09 & $\exp$ & rim interval & $<105$ & 0.026 & 0.13 & 20 & $<0.08$ & na & $<8$ & na & $<0.0041$ & $<0.01$ & 1.48 & 3 & 2.8 & 123 & 1 & 125968 & 253112 \\
\hline ap27c12 & $\exp$ & rim interval & 137 & 0.140 & 1.89 & 20 & 0.48 & na & 5 & na & 0.00757 & 0.09 & 1.08 & 21 & 2.8 & 145 & 67 & 118938 & 229005 \\
\hline ap27d04 & incl & bulk crystal & 506 & 0.044 & 1.53 & 20 & 0.30 & na & 21 & na & 0.00415 & $<0.01$ & 1.37 & 13 & 2.7 & 647 & 30 & 85785 & 179997 \\
\hline
\end{tabular}

<value Concentrations are below the LOD given (3 sigma criterion; Longerich et al., 1996)

na not analyzed

incl grains completely included in quartz crystals

Sc data for zircon are not reported because of ${ }^{90} \mathrm{Zr}^{++}$interference on ${ }^{45} \mathrm{Sc}$ 
Table 3 continued

\begin{tabular}{|c|c|c|c|c|c|c|c|c|c|c|c|c|c|c|c|c|c|c|c|c|}
\hline & $\begin{array}{r}\mathrm{Pr} \\
\mu \mathrm{g} / \mathrm{g}\end{array}$ & $\begin{array}{r}\mathrm{Nd} \\
\mu \mathrm{g} / \mathrm{g}\end{array}$ & $\begin{array}{r}\mathrm{Sm} \\
\mu \mathrm{g} / \mathrm{g}\end{array}$ & $\begin{array}{r}E u \\
\mu \mathrm{g} / \mathrm{g}\end{array}$ & $\begin{array}{r}\text { Gd } \\
\mu g / g\end{array}$ & $\begin{array}{r}\text { Tb } \\
\mu \mathrm{g} / \mathrm{g}\end{array}$ & $\begin{array}{r}\text { Dy } \\
\mu \mathrm{g} / \mathrm{g}\end{array}$ & $\begin{array}{r}\text { Ho } \\
\mu \mathrm{g} / \mathrm{g}\end{array}$ & $\begin{array}{r}E r \\
\mu g / g\end{array}$ & $\begin{array}{r}\mathrm{Tm} \\
\mu \mathrm{g} / \mathrm{g}\end{array}$ & $\begin{array}{r}Y b \\
\mu g / g\end{array}$ & $\begin{array}{r}\mathrm{Lu} \\
\mu \mathrm{g} / \mathrm{g}\end{array}$ & $\begin{array}{l}\mathrm{HfO2} \\
\mathrm{wt} \%\end{array}$ & $\begin{array}{r}\mathrm{Ta} \\
\mu \mathrm{g} / \mathrm{g}\end{array}$ & $\begin{array}{r}\mathrm{Pb} \\
\mu \mathrm{g} / \mathrm{g}\end{array}$ & $\begin{array}{r}B i \\
\mu g / g\end{array}$ & $\begin{array}{r}\text { Th } \\
\mu g / g\end{array}$ & $\begin{array}{r}U \\
\mu / g\end{array}$ & $\begin{array}{c}\mathrm{Ce} / \mathrm{Ce}^{*} \\
\text { Chond-Norm }\end{array}$ & $\begin{array}{c}\text { Eu/Eü } \\
\text { Chond-Norm }\end{array}$ \\
\hline \multicolumn{21}{|c|}{ VNLT 107: Early magmatic zircon } \\
\hline ap27e05 & 134 & 776 & 639 & 7.1 & 1621 & 702 & 7298 & 2046 & 7643 & 1487 & 12456 & 1530 & 1.40 & 48 & na & 1.1 & 4368 & 12873 & 1.1 & 0.021 \\
\hline ap27e05 & 45 & 299 & 385 & 6.5 & 1053 & 483 & 5120 & 1480 & 5699 & 1143 & 10036 & 1233 & 1.44 & 23 & na & $<0.01$ & 4205 & 8940 & 1.3 & 0.031 \\
\hline ap27e03 & 35 & 242 & 293 & 4.1 & 771 & 374 & 4132 & 1198 & 4576 & 978 & 8701 & 1057 & 1.47 & 14 & na & $<0.56$ & 3375 & 9207 & 1.2 & 0.026 \\
\hline ap27e04 & 28 & 174 & 232 & 3.2 & 635 & 300 & 3316 & 977 & 3696 & 777 & 6678 & 855 & 1.45 & 13 & na & 0.17 & 3098 & 6523 & 1.2 & 0.026 \\
\hline \multicolumn{21}{|c|}{ Yankee 8.1 E: Late magmatic zircon } \\
\hline ap27a16 & 0.77 & 4.4 & 14 & $<0.33$ & 94 & 48 & 694 & 299 & 1472 & 347 & 3463 & 642 & 2.24 & 37 & na & $<0.16$ & 2120 & 10894 & 6.1 & $<0.030$ \\
\hline ap27a17 & $<0.6$ & 3.8 & 9.5 & $<0.76$ & 34 & 15 & 213 & 87 & 389 & 88 & 812 & 152 & 1.41 & 4.5 & na & $<0.76$ & 568 & 1374 & $>6.1$ & $<0.137$ \\
\hline ap27c17 & 1.6 & 9.3 & 27 & $<0.55$ & 198 & 100 & 1321 & 531 & 2440 & 520 & 4780 & 844 & 1.65 & 31 & na & $<0.55$ & 6491 & 16350 & 6.9 & $<0.024$ \\
\hline ap27c18 & 1.5 & 9.4 & 16 & $<0.20$ & 105 & 57 & 833 & 359 & 1816 & 427 & 4266 & 792 & 2.16 & 59 & na & 0.78 & 2823 & 15299 & 5.7 & $<0.015$ \\
\hline 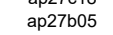 & 27 & $\begin{array}{l}124 \\
121\end{array}$ & 63 & 0.89 & 178 & 75 & 975 & 384 & 1808 & 422 & 4217 & 688 & 1.77 & 82 & na & 0.26 & 3232 & 14643 & $\begin{array}{l}.1 . \\
1.4\end{array}$ & 0.026 \\
\hline ap27b06 & 77 & 375 & 220 & 5.6 & 403 & 133 & 1272 & 401 & 1666 & 392 & 4230 & 678 & 1.97 & 238 & na & 31 & 1758 & 13438 & $\begin{array}{l}1.4 \\
1.3\end{array}$ & 0.058 \\
\hline ap27c08 & 35 & 208 & 144 & $\begin{array}{l}4.0 \\
4.0\end{array}$ & 343 & 118 & 1185 & 375 & 1506 & 320 & 2958 & 475 & 1.75 & $\begin{array}{l}200 \\
38\end{array}$ & na & 0.04 & 3974 & 7186 & 1.5 & 0.055 \\
\hline ap27c14 & 20 & 112 & 53 & 1.7 & 107 & 35 & 382 & 134 & 580 & 132 & 1305 & 228 & 1.83 & 20 & na & 0.33 & 767 & 2991 & 1.5 & 0.070 \\
\hline ap27c15 & 9.9 & 55 & 34 & 1.2 & 89 & 33 & 371 & $\begin{array}{l}134 \\
134\end{array}$ & 601 & 140 & 1429 & 263 & 1.86 & 42 & na & 0.11 & 1317 & 3611 & $\begin{array}{l}1.6 \\
1.6\end{array}$ & 0.068 \\
\hline ap27c16 & 47 & 248 & 180 & 6.5 & 421 & $\begin{array}{l}302 \\
162\end{array}$ & 1709 & 544 & 2237 & 486 & 4559 & 705 & $\begin{array}{l}1.00 \\
1.81\end{array}$ & 56 & na & $<0.01$ & 10940 & $\begin{array}{r}13622 \\
\end{array}$ & $\begin{array}{l}1.0 \\
1.6\end{array}$ & 0.072 \\
\hline ap27a17 & $\begin{array}{l}41 \\
<0.6\end{array}$ & 3.7 & 4.2 & $\begin{array}{l}<0.66 \\
\end{array}$ & 39 & 15 & 191 & $\begin{array}{r}734 \\
73\end{array}$ & 343 & 75 & $\begin{array}{r}729 \\
729\end{array}$ & 134 & 1.60 & 2.7 & $\begin{array}{l}\text { na } \\
\text { nat }\end{array}$ & $<0.66$ & 484 & 993 & $>4.7$ & $<0.164$ \\
\hline ap27b04 & 0.32 & $\begin{array}{l}.1 .1 \\
3.6\end{array}$ & $\begin{array}{l}13 \\
13\end{array}$ & $<0.05$ & 98 & $\begin{array}{l}52 \\
52\end{array}$ & 769 & 333 & $\begin{array}{l}7405 \\
1665\end{array}$ & 394 & 3948 & 711 & 2.03 & 45 & na & 0.24 & $\begin{array}{l}404 \\
2350\end{array}$ & $\begin{array}{r}12524 \\
\end{array}$ & 36 & $\begin{array}{l}<0.004 \\
<\end{array}$ \\
\hline ap27c06 & 0.15 & $\begin{array}{l}1.0 \\
1.5\end{array}$ & $\begin{array}{l}10 \\
5.6\end{array}$ & $<0.11$ & 35 & 18 & 262 & 110 & 581 & $\begin{array}{l}594 \\
152\end{array}$ & $\begin{array}{l}17908 \\
1708\end{array}$ & 328 & $\begin{array}{l}2.09 \\
2.09\end{array}$ & 45 & na & $\begin{array}{l}<0.11 \\
\end{array}$ & 602 & $\begin{array}{r}4164 \\
\end{array}$ & $>17$ & $\begin{array}{l}<0.027 \\
\end{array}$ \\
\hline ap27c07 & 1.5 & 11 & $\begin{array}{l}.0 \\
12\end{array}$ & 0.22 & 48 & $\begin{array}{l}10 \\
21\end{array}$ & 253 & 100 & 442 & 96 & 908 & $\begin{array}{l}320 \\
159\end{array}$ & $\begin{array}{l}2.39 \\
1.32\end{array}$ & $\begin{array}{l}3.3 \\
3.3\end{array}$ & na & $<0.10$ & 574 & $\begin{array}{l}4104 \\
1282\end{array}$ & 4.0 & 0.028 \\
\hline ap27c10 & 0.72 & 5.2 & 12 & $\begin{array}{l}<0.61 \\
<01\end{array}$ & $\begin{array}{l}\text { to } \\
80\end{array}$ & 40 & 568 & 235 & $\begin{array}{l}4093 \\
103\end{array}$ & 251 & 2329 & 413 & 1.72 & 12 & $\begin{array}{l}\text { na } \\
\text { nat }\end{array}$ & 0.74 & $\begin{array}{l}1392 \\
1392\end{array}$ & 6115 & 7.0 & $\begin{array}{l}<0.062 \\
<02\end{array}$ \\
\hline ap27c11 & 1.8 & 11 & 15 & $<0.10$ & 78 & 39 & 531 & 218 & 1030 & 240 & 2360 & 389 & $\begin{array}{l}1.68 \\
1.68\end{array}$ & 18 & na & $<0.10$ & 1730 & 6549 & 4.1 & $<0.009$ \\
\hline ap27c13 & $<0.5$ & 5.1 & 9.1 & $<0.65$ & 79 & 39 & 589 & 250 & 1190 & 281 & 2610 & 479 & 2.00 & 22 & na & $<0.26$ & 1638 & 8224 & $>14$ & $<0.078$ \\
\hline \multicolumn{21}{|c|}{ Hydrothermal zircon (Yankee Lodes) } \\
\hline ap27a03 & 0.28 & 3.4 & 6.4 & 0.14 & 40 & 21 & 308 & 129 & 682 & 180 & 2033 & 406 & 2.66 & 108 & na & $<0.36$ & 663 & 4315 & 15 & 0.027 \\
\hline ap27a15 & & 2.0 & 3.6 & 0.05 & 22 & 13 & 212 & 103 & 617 & 186 & 2279 & 469 & 2.86 & 105 & na & 0.59 & 480 & 4394 & 6.7 & 0.017 \\
\hline 106 & 0.22 & 3.1 & 5.2 & $<0.06$ & 28 & 15 & 228 & 99 & 559 & 157 & 1906 & 398 & 3.41 & 153 & 155 & $<0.19$ & 296 & 4330 & 12 & 16 \\
\hline m_-02a07 & 0.82 & 8.2 & 14 & $<0.15$ & 55 & 21 & 280 & 109 & 583 & 152 & 1781 & 364 & 2.27 & 69 & 198 & $<0.20$ & 1126 & 5466 & 4.0 & $<0.016$ \\
\hline 12 & 1.1 & 7.1 & 10 & $<0.28$ & 44 & 21 & 279 & 113 & 574 & 139 & 1514 & 301 & 2.26 & 39 & 134 & 0.30 & 617 & 3649 & 3.6 & $<0.039$ \\
\hline 16 & $<0.4$ & 2.3 & 3.0 & $<0.47$ & 27 & 12 & 131 & 58 & 298 & 74 & 773 & 159 & 1.92 & 53 & 62 & $<0.90$ & 381 & 1678 & $>6.2$ & $<0.159$ \\
\hline 03 & 0.88 & 6.2 & 13 & 0.20 & 49 & 21 & 267 & 99 & 502 & 136 & 1540 & 310 & 2.08 & 107 & 128 & $<0.31$ & 635 & 3474 & 2.9 & 0.024 \\
\hline 05 & 0.54 & 5.0 & 10 & 0.34 & 64 & 29 & 404 & 169 & 803 & 180 & 1758 & 328 & 1.77 & 30 & 155 & $<0.55$ & 1263 & 4235 & 7.9 & 0.041 \\
\hline 07 & 0.56 & 5.9 & 9.5 & $<0.05$ & 35 & 16 & 204 & 79 & 387 & 98 & 1065 & 208 & 2.17 & 45 & 78 & 0.05 & 358 & 2113 & 5.5 & $<0.008$ \\
\hline $\mathrm{m}$ & 0.53 & 5.9 & 10 & 0.09 & 52 & 25 & 351 & 148 & 774 & 207 & 2328 & 474 & 2.95 & 116 & 212 & 2.6 & 623 & 5289 & 6.5 & 0.012 \\
\hline m_03a11 & 0.80 & 8.6 & 13 & $<0.06$ & 47 & 20 & 251 & 97 & 501 & 134 & 1556 & 28 & 2.62 & 96 & 133 & 0.20 & 579 & 3722 & 4.3 & $<0.007$ \\
\hline m_03a15 & 0.48 & 4.4 & 5.9 & 0.11 & 23 & 13 & 167 & 73 & 409 & 123 & 1531 & 14 & 2.20 & 84 & 165 & $<0.15$ & 525 & 3512 & 28 & 0.030 \\
\hline ар27a11 & 0.40 & 4.3 & 5.3 & 0. & 26 & 14 & 225 & 107 & 656 & 209 & 2812 & 8 & 4.46 & 277 & na & $<0.08$ & 247 & 3971 & 5.0 & 0.022 \\
\hline ap27a12 & 1.2 & 9.5 & 9.4 & 0.0 & 35 & 18 & 268 & 122 & 716 & 220 & 2805 & 84 & 4.26 & 290 & na & $<0.14$ & 391 & 4479 & 2.7 & 0.009 \\
\hline ap27a14 & 0.24 & 3.4 & 8.7 & 0. & 60 & 31 & 436 & 188 & 924 & 219 & 2191 & 20 & 2.10 & 46 & na & $<0.07$ & 1142 & 5834 & 39 & 0.015 \\
\hline ap27a15 & 0.23 & 2.1 & 4.1 & 0. & 25 & 14 & 221 & 105 & 619 & 183 & 2197 & 447 & 2.67 & 92 & na & $<0.09$ & 573 & 4248 & 11 & 0.016 \\
\hline 5 & 0.11 & 1.3 & 1.9 & 0. & 15 & 8 & 121 & 55 & 302 & 91 & 1143 & 239 & 2.63 & 110 & na & $<0.08$ & 95 & 2074 & 5.4 & 4 \\
\hline ap27a06 & 0.29 & 2.2 & 4.5 & 0. & 22 & 11 & 153 & 65 & 318 & 79 & 886 & 177 & 1.86 & 43 & na & 0.20 & 218 & 1609 & 6.5 & 0.100 \\
\hline & 0.08 & 1.0 & 2.6 & 0. & 17 & 9 & 134 & 59 & 323 & 90 & 1082 & 230 & 2.25 & 89 & na & $<0.31$ & 236 & & 17 & 0.065 \\
\hline ap27a14 & 0.29 & 2.8 & 8.0 & 0 & 51 & 27 & 384 & 165 & 812 & 194 & 1988 & 381 & 2.29 & 62 & na & $<0.39$ & 1047 & 6187 & 19 & 0.058 \\
\hline m_03a16 & 0.12 & 1.5 & 5.1 & $<0.10$ & 34 & 17 & 241 & 106 & 551 & 138 & 1495 & 301 & 2.20 & 87 & 135 & 0.20 & 539 & 3239 & $>46$ & $<0.022$ \\
\hline \multicolumn{21}{|c|}{ Gadet 6.2: Zircon associated with biotite alteration (Paradise Lode) } \\
\hline ap27f03 & 138 & 655 & 347 & 13 & 738 & 218 & 1824 & 459 & 1642 & 350 & 3332 & 527 & 2.45 & 24 & na & 0.46 & 1383 & 5519 & 1.5 & 0.082 \\
\hline & 12 & 67 & 60 & 1.9 & 160 & 49 & 409 & 113 & 406 & 80 & 733 & 118 & 1.43 & 3.0 & na & $<0.13$ & 303 & 910 & 1.5 & 0.060 \\
\hline & 98 & 483 & 284 & 10 & 582 & 177 & 1454 & 373 & 1316 & 260 & 2313 & 334 & 1. & 6.7 & na & 0.21 & 1270 & 3430 & 1.5 & 0.078 \\
\hline & 4.4 & 32 & 35 & 2.0 & 124 & 42 & 378 & 108 & 406 & 80 & 680 & 112 & 1. & 1.0 & na & 0.06 & 280 & 297 & 1.5 & 0.091 \\
\hline & 295 & 1347 & 692 & 26 & 1319 & 440 & 3807 & 948 & 3381 & 699 & 6285 & 905 & 1. & 71 & na & 4.7 & 4637 & 12025 & 1.6 & 0.083 \\
\hline & 5.0 & 30 & 24 & 1.0 & 78 & 25 & 233 & 69 & 270 & 55 & 501 & 86 & 1.32 & 2.0 & na & $<0.08$ & 276 & 645 & 1.7 & 0.070 \\
\hline 0 & 282 & 1374 & 708 & 28 & 1221 & 368 & 2910 & 694 & 2437 & 532 & 5312 & 868 & 3.35 & 84 & na & 0.15 & 1678 & 11155 & 1.6 & 0.091 \\
\hline ap27f09 & 56 & 296 & 185 & 5.4 & 410 & 127 & 1016 & 258 & 883 & 169 & 1439 & 224 & 1.41 & 6.1 & na & $<0.14$ & 943 & 2097 & 1.3 & 0.060 \\
\hline ap27f12 & 353 & 1644 & 779 & 29 & 1293 & 385 & 3057 & 725 & 2471 & 505 & 4619 & 665 & 1.91 & 51 & na & 1.1 & 2737 & 19314 & 1.5 & 0.089 \\
\hline \multirow[t]{2}{*}{ ap27f11 } & 98 & 499 & 321 & 9.4 & 689 & 204 & 1584 & 386 & 1284 & 242 & 2037 & 314 & 1.36 & 12 & na & 0.21 & 928 & 3799 & 1.3 & 0.061 \\
\hline & $\begin{array}{r}\mathrm{Pr} \\
\mathrm{ppm}\end{array}$ & $\begin{array}{r}\mathrm{Nd} \\
\mathrm{ppm}\end{array}$ & $\underset{\mathrm{ppm}}{\mathrm{Sm}}$ & $\begin{array}{r}\mathrm{Eu} \\
\mathrm{ppm}\end{array}$ & $\begin{array}{r}\mathrm{Gd} \\
\mathrm{ppm}\end{array}$ & $\begin{array}{r}\mathrm{Tb} \\
\mathrm{ppm}\end{array}$ & $\begin{array}{r}\mathrm{Dy} \\
\mathrm{ppm}\end{array}$ & $\begin{array}{r}\mathrm{Ho} \\
\mathrm{ppm}\end{array}$ & $\begin{array}{r}\mathrm{Er} \\
\mathrm{ppm}\end{array}$ & $\underset{\mathrm{ppm}}{\mathrm{Tm}}$ & $\begin{array}{r}\mathrm{Yb} \\
\mathrm{ppm}\end{array}$ & $\begin{array}{r}\mathrm{Lu} \\
\mathrm{ppm}\end{array}$ & $\begin{array}{r}\mathrm{Hf} \\
\mathrm{ppm}\end{array}$ & $\begin{array}{r}\mathrm{Ta} \\
\mathrm{ppm}\end{array}$ & $\begin{array}{r}\mathrm{Pb} \\
\mathrm{ppm}\end{array}$ & $\begin{array}{r}\mathrm{Bi} \\
\mathrm{ppm}\end{array}$ & $\begin{array}{c}\text { ThO2 } \\
\text { wt } \%\end{array}$ & $\begin{array}{l}\text { vo2 } \\
\text { wt } \%\end{array}$ & $\begin{array}{c}\mathrm{Ce} / \mathrm{Ce}^{*} \\
\text { Chond-Norm }\end{array}$ & $\begin{array}{c}\text { Eu/Eu } u^{*} \\
\text { Chond-Norm }\end{array}$ \\
\hline Yankee 8.1 E & Late $\mathrm{m}$ & gmatic $t$ & orite & & & & & & & & & & & & & & & & & \\
\hline ap27b03 & 142 & 1218 & 992 & 0. & 17 & 46 & 34 & 76 & 20 & 27 & 16 & 186 & 9.4 & 0. & na & 0. & 54 & 22 & 1.4 & 0.0009 \\
\hline & 141 & 12 & 980 & 0. & 1774 & 460 & & 75 & 2032 & 277 & 16 & 186 & 9.1 & 0. & na & 0.0 & 54. & 22.49 & 1.5 & 0.0008 \\
\hline ap27a18 & 170 & 1415 & 1014 & 0.42 & 1815 & 424 & 2985 & 670 & 1750 & 221 & 1228 & 140 & 6.5 & 0.48 & na & 0.11 & 60.4 & 16.71 & 1.2 & 0.0009 \\
\hline Hydrotherm & thorite & & & & & & & & & & & & & & & & & & & \\
\hline 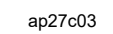 & 16 & 14 & & 2 . & & 455 & & 0 & 15 & 18 & 95 & 11 & 6.3 & & na & 0 & 6 & 15 & 1.4 & 0.0047 \\
\hline & 19 & 1678 & 118 & 1.1 & 21 & 46 & & 65 & 1608 & 188 & 9 & 11 & 4.1 & & na & $<0.01$ & 63 & 13 & 1.4 & 0.0021 \\
\hline & 100 & 94 & 93 & 1.8 & 1809 & 45 & 31 & 67 & 1749 & 241 & 149 & 175 & 2.5 & $<0.22$ & a & 0. & 52 & 25.30 & 1.4 & 0.0043 \\
\hline m_03a12 & 40 & 407 & 423 & 4.5 & 840 & 174 & 1208 & 259 & 670 & 88 & 571 & 63 & 3.7 & 0.27 & 41538 & $<1.2$ & 55.9 & 23.21 & 1.6 & 0.0232 \\
\hline m_03a13 & 46 & 413 & 453 & 3.6 & 853 & 204 & 1384 & 292 & 773 & 116 & 756 & 96 & 1646 & 15 & 40615 & $<0.50$ & 55.5 & 21.71 & 1.3 & 0.0176 \\
\hline
\end{tabular}

Yankee 8.1 E: Late magmatic monazite

\begin{tabular}{|c|c|c|c|c|c|c|c|c|c|c|c|c|c|c|c|c|c|c|c|}
\hline $\begin{array}{r}\mathrm{Pr} \\
\mathrm{ppm}\end{array}$ & $\begin{array}{r}\mathrm{Nd} \\
\mathbf{p p m}\end{array}$ & $\begin{array}{r}\mathrm{Sm} \\
\mathrm{ppm}\end{array}$ & $\begin{array}{r}\mathrm{Eu} \\
\mathrm{ppm}\end{array}$ & $\begin{array}{r}\mathrm{Gd} \\
\mathrm{ppm}\end{array}$ & $\begin{array}{r}\text { Tb } \\
\text { ppm }\end{array}$ & $\begin{array}{r}\text { Dy } \\
\text { ppm }\end{array}$ & $\begin{array}{r}\text { Ho } \\
\text { ppm }\end{array}$ & $\begin{array}{r}E r \\
\text { ppm }\end{array}$ & $\underset{\mathrm{ppm}}{\mathrm{Tm}}$ & $\begin{array}{c}\mathrm{Yb} \\
\mathrm{ppm}\end{array}$ & $\begin{array}{r}\mathrm{Lu} \\
\mathrm{ppm}\end{array}$ & $\begin{array}{r}\mathrm{Hf} \\
\mathbf{p p m}\end{array}$ & $\begin{array}{r}\mathrm{Ta} \\
\mathrm{ppm}\end{array}$ & $\begin{array}{c}\mathrm{Pb} \\
\mathrm{ppm}\end{array}$ & $\begin{array}{r}\mathrm{Bi} \\
\mathrm{ppm}\end{array}$ & $\begin{array}{r}\text { ThO2 } \\
\text { wt } \%\end{array}$ & $\begin{array}{l}\text { uo2 } \\
\mathbf{w t} \%\end{array}$ & $\begin{array}{c}\mathrm{Ce} / \mathrm{Ce}^{\star} \\
\text { Chond-Norm }\end{array}$ & $\begin{array}{c}\text { Eu/Eu* } \\
\text { Chond-Norm }\end{array}$ \\
\hline 28032 & 104967 & 16 & 11 & 96 & 1042 & 405 & 531 & 851 & 64 & 20 & 19 & 1.4 & 0.9 & na & $<0.70$ & .4 & 0.28 & 1.0 & .0026 \\
\hline 24341 & 92880 & 13070 & 24 & 7554 & 780 & 2992 & 411 & 643 & 50 & 184 & 10 & 1. & 1. & nda & 0.45 & 18.8 & 0.25 & 1.0 & 0.0073 \\
\hline 20190 & 78336 & 12665 & 12 & 7848 & 893 & 3585 & 500 & 799 & 63 & 241 & 21 & 1.6 & 0.4 & na & 0.65 & 30.6 & 0.51 & 1.0 & 0.0036 \\
\hline
\end{tabular}


Table 4: Zircon - melt distribution coefficients: Mole Granite and literature data

\begin{tabular}{|c|c|c|c|c|c|c|c|}
\hline & $\begin{array}{r}\text { zircon } \\
\text { early magmatic } \\
\mu \mathrm{g} / \mathrm{g} \\
\mathrm{n}=4\end{array}$ & $\begin{array}{r}\text { Mole Granite } \\
\text { bulk rock } \\
\mu \mathrm{g} / \mathrm{g} \\
\mathrm{n}=14\end{array}$ & $\begin{array}{r}\mathrm{D}\left(\mathrm{X}_{\text {zircon }} / \mathrm{X}_{\text {melt }}\right) \\
\text { Mole Granite }\end{array}$ & $\begin{array}{r}\mathrm{D}\left(\mathrm{X}_{\text {zircon }} / \mathrm{X}_{\text {melt }}\right) \\
\text { MMM Pluton } \\
\text { ref. } 1\end{array}$ & $\begin{array}{r}\mathrm{D}\left(\mathrm{X}_{\text {zircon }} / \mathrm{X}_{\text {melt }}\right) \\
\text { Rhyolite } 1 \\
\text { ref. } 2\end{array}$ & $\begin{array}{r}\mathrm{D}\left(\mathrm{X}_{\text {zircon }} / \mathrm{X}_{\text {melt }}\right) \\
\text { Rhyolite } 2 \\
\text { ref. } 2\end{array}$ & $\mathrm{D}\left(\mathrm{X}_{\text {zircon }} / \mathrm{X}_{\text {melt }}\right)$ \\
\hline $\mathrm{Li}$ & 13 & 55 & 0.2 & & & & \\
\hline Y & 40000 & 75 & 530 & & & & \\
\hline $\mathrm{Nb}$ & 96 & 9.9 & 10 & & & & \\
\hline Sn & 46 & 6.0 & 7.7 & & & & \\
\hline Cs & 44 & 24 & 1.8 & & & & \\
\hline La & 79 & 43 & 1.8 & 3 & 7 & 27 & 0.08 \\
\hline $\mathrm{Ce}$ & 320 & 100 & 3.2 & 2 & 10 & 24 & 1 \\
\hline $\operatorname{Pr}$ & 58 & 12 & 4.8 & & & & \\
\hline $\mathrm{Nd}$ & 360 & 41 & 8.6 & & 5 & 22 & 0.5 \\
\hline $\mathrm{Hf}$ & 12000 & 4.1 & 2900 & 1190 & 3742 & 2645 & \\
\hline $\mathrm{Ta}$ & 23 & 1.8 & 13 & 5 & 40 & 55 & \\
\hline Th & 3600 & 47 & 77 & 15 & 91 & 62 & \\
\hline U & 9000 & 17 & 530 & 173 & 383 & 298 & \\
\hline
\end{tabular}

ref. 1 Sawka (1988)

ref. 2 Mahood and Hildred (1983)

ref. 3 Thomas et al. (2002); data from melt inlcusions host zircon pairs $(n=11)$ 
Table 5: Hydrothermal zircon - fluid distribution coefficients for the Yankee Lodes

\begin{tabular}{|c|c|c|c|c|c|c|c|}
\hline FI-number ${ }^{\&}$ & Fl-type & $\begin{array}{r}L i \\
\mu g / g\end{array}$ & $\begin{array}{r}S n \\
\mu g / g\end{array}$ & $\begin{array}{r}\text { Cs } \\
\mu g / g\end{array}$ & $\begin{array}{r}\mathrm{Ce} \\
\mu \mathrm{g} / \mathrm{g}\end{array}$ & $\begin{array}{r}\mathrm{Pb} \\
\mu \mathrm{g} / \mathrm{g}\end{array}$ & $\begin{array}{r}B i \\
\mu g / g\end{array}$ \\
\hline 112 & brine & 1280 & 32 & 1981 & 0.6 & 2028 & 7.9 \\
\hline 113 & brine & 1167 & & 2357 & 1.1 & & 1.3 \\
\hline 115 & brine & 1276 & 49 & 2875 & 0.9 & 2468 & 4.1 \\
\hline 125 & brine & 1534 & 13 & 3148 & 1.1 & 2287 & \\
\hline 126 & brine & 1531 & & 3337 & & 2941 & \\
\hline 127 & brine & 1190 & 657 & 3655 & 0.6 & 2139 & \\
\hline 128 & brine & 2008 & 216 & 3605 & & 2538 & \\
\hline 129 & brine & 1336 & 407 & 2522 & & 1850 & \\
\hline 130 & brine & 1367 & 700 & 2633 & & 3098 & \\
\hline 131 & brine & 1371 & 418 & 3227 & 0.7 & 2489 & \\
\hline 132 & brine & 1572 & 747 & 3279 & 1.0 & 3422 & \\
\hline average & brine & 1400 & 360 & 3000 & 0.9 & 2500 & 4 \\
\hline 1 stdev & brine & 200 & 300 & 500 & 0.2 & 500 & 3 \\
\hline average & Hyd. Zircon * & 134 & 210 & 2.0 & 12 & $<2^{\#}$ & 0.3 \\
\hline 1 stdev & Hyd. Zircon * & 106 & 85 & 1.7 & 6 & - & 0.2 \\
\hline$n=$ & & 12 & 12 & 11 & 12 & 10 & 4 \\
\hline $\mathrm{D}\left(\mathrm{X}_{\text {zircon }} / \mathrm{X}_{\text {fluid }}\right)$ & & 0.1 & 0.6 & 0.001 & 14 & $<0.001$ & 0.1 \\
\hline
\end{tabular}

\& data from Audétat (1999)

* bulk crystal data from table 3

\# average value of 12 common $\mathrm{Pb}$ estimates

(from bulk $\mathrm{Pb}$ measurements corrected for in-situ growth of radiogenic $\mathrm{Pb}$ ) 